\title{
A FEASIBILITY STUDY OF MODELING PEDOGENIC CARBONATES IN SOILS AND SEDIMENTS AT THE U.S. DEPARTMENT OF ENERGY'S HANFORD SITE
}

C. R. Hunter

A. J. Busacca

Washington Siate University

Pullman, Washington

W. J. Waugh

PNL Project Manager

September 1990

Prepared by Washing:on State University for Pacific Northwest Laboratory under Contract DE-AC06-76RLO 1830 with the $I^{\top} . S$. Department of Energy under Agreement B-N9191-A-6 


\section{SUMMARY}

This study was conducted for Pacific Northwest Laboratory by Washington State University in support of the U.S. Department of Energy's Protective Barrier and Warning Marker System Development Program. The obiective of this study was to determine the feasibility of 1 ) deriving information about past water movement patterns from Holocene-age soils in the Hanford region, and 2) using mathematical simulation modeling of pedogenic carbonate accumulations in layered sediments as a performance assessment tool for protective barrier development. The pedogenic carbonate models would serve two purposes in barrier performance assessment: 1) to reconstruct Holocene water movement from the distribution of carbonates in layered sediments as an analog of future water movement in protective barriers, and 2) to simulate the feedback effect of carbonate accumulation on soil hydraulic properties and unsaturated recharge in proposed protective barrier designs.

The study progressed in three phases. The first phase was a review and interpretation of current literature on pedogenic indicators of water movement. The review focused on pedogenic and lithogenic processes that drive carbonate accurnulation in arid land soils and simulation models linking carbonate distribution to soil hydraulic properties, soil water balance, and climate. The second phase of the feasibility study identified issues and limitations associated with applying or modifying existing computer simulation codes or developing a new code. Finally, the utility of proceeding with the project was determined based on an evaluation of issues and limitations in relation to barrier performance criteria.

The following is a summary of the synthesis of existing literature. The most significant pedogenic indicators of soil water movement in arid and semiarid environments are clay, silt, and soluble salts, including calcium carbonate. Based on existing studies of soils at the Hanford Site and the personal knowledge of the authors about soil characteristics in eastern Washington, the accumulation of $\mathrm{CaCO}_{3}$ is the most likely pedogenic indicator of water movement at the Hanford Site. The geochemistry of $\mathrm{CaCO}_{3}$ is relatively simple and depends upon the availability of $\mathrm{Ca}^{2+}, \mathrm{pCO}_{2}$, and water. Two mechanisms have been identified as being primarily responsible for carbonate precipitation in soils: evapotranspiration and degassing of $\mathrm{CO}_{2}$. Thus, it is likely there is both a biotic and an abiotic component involved in the precipitation of carbonate in soil. The relative importance of both of these processes has been demonstrated using techniques such as isotope geochemistry, micromorphology, and cathodoluminescence. The amount and morphology of carbonates in soils are also a function of the progressive accumulation of carbonate over time. 
Two systems models (CALDEP and CALSOIL) that simulate the accumulation of $\mathrm{CaCO}_{3}$ were examined. Although there are functional differences between the two models, especially in modeling climate and the feedbacks between carbonate accumulation and soil porosity, both models utilize saturated flow as the mechanism for water and solute transport. It was determined that CALSOIL is most sensitive to soil and climate parameters that influence water movement such as water holding capacity and rainfall. However, it was concluded that neither the CALSOIL nor CALDEP model effectively simulates the conditions expected in the protective barriers.

Based on the literature synthesis and sensitivity analysis of simulation models, along with observations of Hanford soils, several issues and limitations associated with the use of natural analogs and simulation modeling in support of the goals of this project were identified:

1) It is probably prudent to abandon the concept that the depth at which carbonates precipitate $i$ 's the depth below which no unsaturated recharge occurs. The presence of a calcic horizon only indicates that the soil solution became supersaturated with respect to carbonate, not that water flow stopped completely.

2) Based upon known characteristics of Hanford soils, it is quite evident that carbonates have accumulated in soils during the Holocene. Because unsaturated flow has been demonstrated through the soil layer of the proposed protective barier design, unsaturated flow prcbably also occurred during the formation of calcic horizons during the Holocene.

3) Natural analogs cannot be used as a means of validating models if they are also to be used to test different climatic scenarios. Independent verification of Holocene climatic scenarios may come from other phases of the natural analog research. Sensitivity analysis may also provide an alternative means of model validation.

4) The natural analogs can be used to measure hydraulic properties of calcic horizons and compare them to noncalcic soils in order to determine the likely influence of carbonate accumulations on wate $i$ movement in the protective barriers.

Therefore, the natural analogs do not directly' answer the recharge question, but do indicate that calcic horizons will form in the protective barriers. The question remains, however, how much, when, and where the carbonate will accumulate. There exists enough uncertainty at this time about the effect of carbonate accumulations on the hydraulic properties, that work should continue at least through the project planning phase. How much impact carbonate accumulation has on hydraulic properties of soils is considered a primary research need. 


\section{CONTENTS}

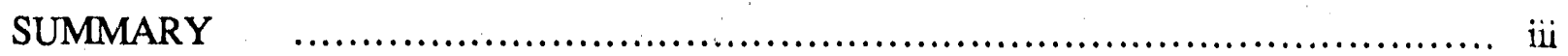

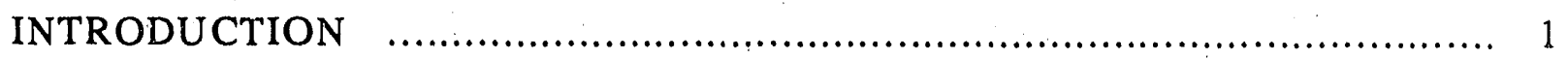

LITERATURE REVIEW ........................................................... 2

NON-CARBONATE PEDOGENIC INDICATORS OF SOIL

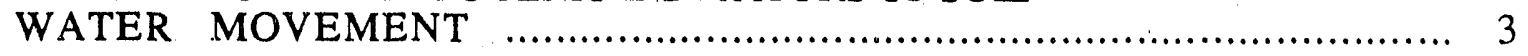

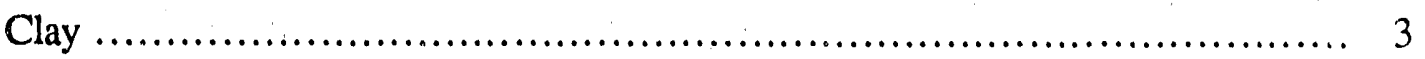

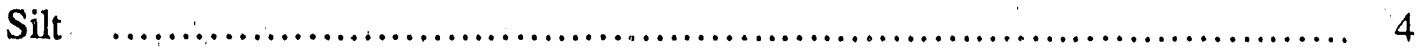

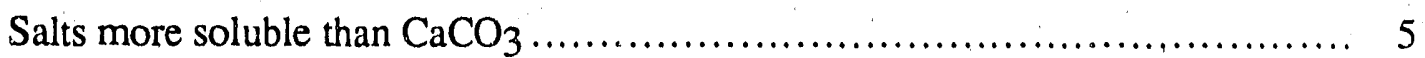

CALCIUM CARBONATE AS A PEDOGENIC INDICATOR OF

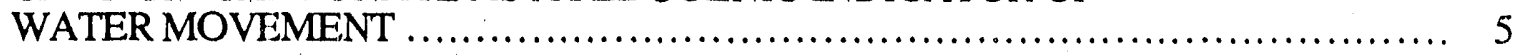

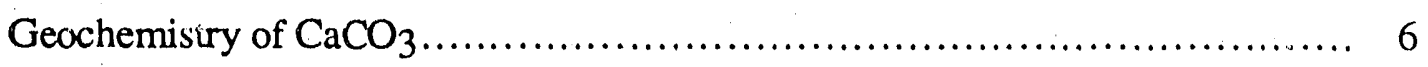

Carbonate accumulations in soils and sediments .............................. 9

MODELING PEDOGENIC ACCUMULATIONS OF CARBONATE IN SOILS........ 17

ISSUES AND LIMITATIONS ASSOCIATED WTIH STUDY OF ANALOG

SOILS AND WTTH SIMULATION MODELING OF PEDOGENIC CARBONATE ... 19

ISSUES ASSOCIEATE WTTH APPLYING SIMULATION MODELS TO

SOILS AT THE HANFORD SITE.......................................................... 20

Natural analog soils of the Hanford area: simple or complex?........................ 20

MODEL ATTRIBUTES .......................................................... 27

Existing Simulation Models ............................................. 27

Sensitivity analysis of CALSOIL ........................................ 29

MODELNG CARBONATES AS A PERFORMANCE ASSESSMENT TOOL ........ 32

SUMMARY AND RECOMMENDATION ....................................... 35

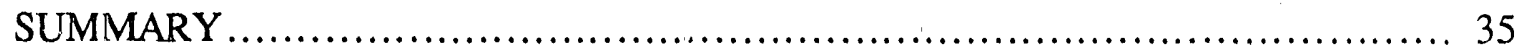

RECOMMENDATION ................................................... 36

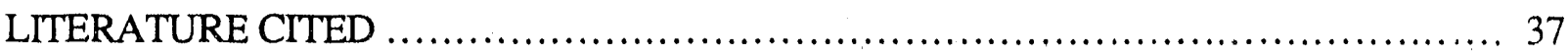

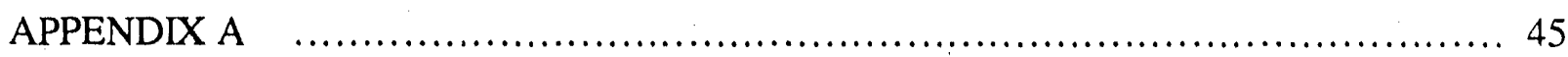




\section{FIGURES}

1. Schematic drawing of profile morphology at the sage brush site of the weighing lysimeter facility, Arid Lands Ecology Reserve.

2. Profile morphology and vertical distribution of calcium carbonate, sand, silt, and clay for the sagebrush 1E (SB 1E) and bunchgrass $1 \mathrm{~W}$ (BG1W) sites of the weighing lysimeter facility, Arid Land Ecology Reserve................................................. 23

3. Synthetic distribution of carbonate using initial conditions outlined ..................... 30

4. Synthetic carbonate dis'ribution comparing the simulation using the initial conditions with the distribution using a sand interface at $20 \mathrm{~cm}$. 


\section{INTRODUCTION}

Radioactive, hazardous, and other kinds of waste have been generated at the Hanford Site throughout its years of operation. It is likely that future operations will produce additional quantities of similar types of waste. Consequently, the permanent disposal of Hanford Site wastes will require remediation of existing waste disposal sites and the long-term isolation of newly generated wastes. Layered, earthen protective barriers have been proposed as one means of inhibiting water, plants, and animals from contacting near-surface hazardous and radioactive waste buried at the Hanford Site, and potentially transporting contaminants to the groundwater or to the land surface. At present, the focus of development efforts is to provide a protective barrier that will remain functional and maintenance free for up to 10,000 years, despite the occurrence of potentially disruptive events (Wing, 1988).

In support of the design of protective barriers and the assessment of their performance, tasks have been identified that may help to resolve the technical concerns. One of these tasks is the study of natural analogs of the proposed protective barrier. The objective of using natural analogs is to better understand the potential long-term behavior of barriers by studying geological and ecological settings that may be analogous either to components of the proposed protective barrier systems or to measures of barrier performance (Wing, 1988). It is expected that natural analogs can provide information about processes affecting waste containment that cannot be fully explored through modeling, laboratory experimentation, or field studies because of the 10,000 -year period of performance.

One task of the natural analogs study is to identify "pedogenic indicators of soil water movement" in the belief that pedogenic morphological features of the soil (especially calcium carbonate) may be indicative of long-term patterns of soil water movement. To accomplish this task it was envisioned that natural analog soils near the Hanford Site would be characterized to establish the probable origin of pedologic indicators of water movement and to model the causal factors of pedogenic accumulations. Such information should provide insight into the ability of protective barriers to control water infiltration to the waste zone over the time period of performance (Wing, 1988).

The objective of this report is to determine the feasibility of 1) deriving information about past water movement patterns by a study of Holocene-age soils in the Hanford region, and 2) using mathematical simulation modeling of pedogenic carbonate accumulations in layered sediments as a performance assessment tool for protective barrier development. Pedogenic carbonate model(s) would serve two purposes in barrier performance assessment: 1) to reconstruct Holocene water 
movement from the distribution of carbonates in layered sediments as an analog of future long-term water movement in protective barriers, and 2) to simulate the feedback effect of carbonate accumulation on soil hydraulic properties and unsaturated recharge in proposed protective barrier designs.

There are three components of this feasibility study: 1) an exhaustive review and interpretation of current literature on pedogenic indicators of soil-water movement including, but not necessarily limited to, pedogenic and lithogenic processes that drive carbonate accumulation in arid land soils, and simulation models linking carbonate distribution to soil hydraulic properties, soil water bal. ance, and climate; 2) identification of issues and limitations (including sensitivity and uncertainty analyses) associated with applying or modifying existing computer simulation codes, or developing a new code; and 3) determination of the utility of proceeding with the project based on an evaluation of issues and limitations in relation to barrier performance criteria.

\section{LITERATURE REVIEW}

The formation of a soil profile (pedogenesis) has been viewed by Simonson $(1959,1978)$ as a result of the combined effect of four major sets or families of processes: 1) additions of solid and soluble material to the soil, 2) transformations of organic and inorganic solid phases, 3) transfers of soluble and solid phases within the soil, and 4) removals of soluble and solid material from the soil profile. Transfers generally involve the movement of ions and particulate matter with the soil water; soluble materials move with the water until changing chemical conditions or dehydration cause them to precipitate; whereas, solid particulate materials move downward until there is a decrease in the electrokinetic potential of the soil water, causing deposition. The accumulations of material moved under the influence of water (precipitated solutes or deposited solids) are the most likely candidates to serve as proxy pedogenic indicators of soil water movement.

Given the nature of conditions at the Hanford Site, especially the arid climate, the following literature review of pedogenic indicators of soil water movement has focused on material transfers that might be expected in arid or semiarid climates. Materials that are subject to possible transfer and accumulation by soil water in arid climates include clay, silt, calcium carbonate, and salts more soluble that calcium carbonate (soluble salts for purposes of this discussion). Our discussion will be divided into two parts: 1) non-carbonate indicators of soil water movement, which include transfers of clays, silts, and soluble salts and 2) carbonate accumulation in soils and sediments. 
This division is appropriate, given existing characterization data of soils and sediments at the Hanford Site (McDonald, 1987a) and the authors' knowledge of likely pedogenic processes in the arid and semiarid regions of eastern Washington.

\section{NON-CARbonate PEdogenic INDICATORS OF SOIL W ATER MOVEMENT}

Clay

Several processes have been proposed to account for non-uniform distribution of clay with depth in soil profiles: 1) stratification of parent material; 2) clay formation in place by mineral weathering; 3 ) movement of soluble constituents of clay by percolating soil water and precipitation as new clay minerals in the B horizon; or 4) movement of clay particles by suspension in percolating soil water until flocculation or constriction in pores causes deposition (Birkeland, 1984). The first is a gengenic rather than a pedogenic feature. No doubt clays of argillic horizons are derived by the latter three processes, but the role of water movement in two of the three envisioned processes should be stressed. Although it is possible that clay may form from the precipitation of soluble constituents (Kittrick, 1970), there is no way, at present, to distinguish clays so formed from clays that are formed by transformation of other pre-existing phyllosilicates or from those inherited from parent material and subsequently translocated. Consequently, the following discussion will center on the movement of clay particles in suspension.

For clay to move it must be dispersed so that it can remain in suspension while soil water moves through the profile. The ionic composition of the soil solution is a dominant factor controlling the mobility of clay. Thus, highly hydrated ions such as $\mathrm{Na}^{+}$at low concentrations are more effective than $\mathrm{Ca}^{2+}$ or $\mathrm{Al}^{3+}$ ions at the same concentrations for dispersing soil clays and enhancing clay movement (Bohn et al., 1985). At higher solution concentrations, however, all ions can cause flocculation and thus inhibit movement. The exact chemical relationships that lead to clay dispersion and movement in one instance or flocculation arid deposition in another are uncertain, but are likely to be extremely dependent upon the kind and quantity of clay in the soil.

In addition to a dependence on the chemical characteristics of soil water and clay minerals themselves, clay movement also involves the physical processes of water movement. In soils that are subject to periodic cycles of wetting and drying, wetting a soil can lead to disruption of the soil fabric and dispersion of the fine clay. Once dispersed, the clay is believed to move with the water 
that percolates at high matric potentials. As water flow becomes increasingly dependent on the small diameter pores (at low matric potentials) the clays in suspension are deposited on the walls of the pores (Fanning and Fanning, 1989)

The exact mechanisms of clay eluviation and illuviation are still poorly understood. It is likely that clay movement and deposition occurs primarily in soils that are subject to drying and leaching after soluble salts and carbonates have been largely removed and in those that contain an abundant quantity of fine clay $(<0.002 \mathrm{~mm}$ ) for transport (either inherited from parent material or produced by weathering; Bartelli and Odell, 1960; McKeague and St. Arnaud, 1969; Soil Survey Staff, 1975; Sehgal, et al., 1976; Duchaufour, 1982). In a study of clay movement through a calcareous soil, Goss et al. (1973) found that added clay could indeed move through a calcareous soil, but only if the pore size was large enough. In the absence of large pores, flow was restricted, and clay deposition occurs, presumably due in part to flocculation by the presence of soluble $\mathrm{Ca}^{2+}$.

Evidence that carbonates are effective in stopping the movement of clays is also found in the morphology of soil profiles. The zone of accumulated clays (argillic horizons), for example, is commonly in or just above a calcareous horizon in a soil with a noncalcareous matrix (Gile et al., 1966). There does not seem to be much evidence for the reverse situation (where carbonate accumulations overlie argillic horizons), although both Aguilar et al. (1983) and Reheis (1987) reported the presence of soils with alternating clay and carbonate accumulations. They both hypothesized that this situation occurred as a result of alternating climates, with clay being translocated during periods of greater rainfall, which would partially remove carbonates from the profile and allow the clay to be mobilized and moved in the profile. The clays became immobilized as they encountered carbonate accumulation in the soil profile or decreased porosity. During drier climates, only carbonates (added as eolian dust) were mobilized, which then engulfed the illuviated clays.

Silt

The translocation of silt particles $(0.002$ to $0.05 \mathrm{~mm}$ in diameter) is a phenomenon that has been reported in studies of soil pedons found in the Arctic and in alpine environments (Locke and Mabee, 1979; Burns, 1982; Birkeland, 1984; Forman and Miller, 1984). Although many of the soils that exhibit features of silt translocation are found in cold climates, it appears that mechanisms other than frost sorting may be responsible for silt translocation. Translocation of the silt by soil water through a coarse-grained soil matrix is the favored hypothesis at the present time (Birkeland 1984; Forman and Miller, 1984). No other information about the range of soil properties necessary for this process to occur is available. 


\section{Salts more soluble than $\mathrm{CaCO}_{3}$}

In humid areas, soluble salts are commonly leached out of soils, but in ari.1 and semiarid regions ( $<300 \mathrm{~mm}$ precipitation/year) horizons of salt accumulation may occur (Birkeland, 1984). The dominant soluble salts are usually chlorides, bicarbonates, and sulfates of $\mathrm{Na}^{+}$and $\mathrm{Mg}^{2+}$, or chlorides and sulfates of $\mathrm{Ca}^{2+}$ (McKeague and St. Arnaud, 1969). Soluble salts may move laterally, upward, or downward in the soil profile, depending upon the dominant direction of water movement. In the presence of a shallow water table, the dominant direction or even seasonal patterns of water movement may be upward or lateral depending upon the evaporative potential of the site. Soluble salts may accumulate in near surface horizons due to upward flow of capillary water (Várallyay, 1968; Hassan and Ghaibeh, 1977; Mahjoory, 1979; Fullerton and Pawluk, 1987). In the absence of a water table, salts are often "wicked" to surface from deeper horizons under the influence of evaporation and transpiration (Fanning and Fanning, 1989). Accumulation of soluble salts in soil profiles indicates the presence of extreme desiccation, but does not necessarily reflect only downward movement of water in the soil profile.

\section{Calcium Carbonate as a Pedogenic Indicator of Water Movement}

Calcium carbonate is a common feature in soils and sediments of arid and semiarid environments (Klappa, 1983). In many soils of these regions it forms the most prominent horizon (Gile et al., 1966; Birkeland, 1984; Machette, 1985; McFadden and Tinsley, 1985). The processes responsible for the formation of calcic horizons (accumulations of $\mathrm{CaCO}_{3}$ ) in soils are difficult to ascertain because of the muititucle of environments in which they are found (Reeves, 1976). Reeves cited evidence for six models by which calcium carbonate may accumulate in soils or sediments: 1) the fluvial model relates to the precipitation of calcic materials along stream valleys and channels; 2) the lacustrine model explains the formation of calcic materials adjacent to ancient lakes and playas; 3 ) the in situ model relegates calcic horizon formation to decomposition and accumulation of parent carbonate material (e.g., coral reef deposits); 4) the capillary rise model refers to calcic horizons formed by ascending soil water from a shallow water table during dry periods; 5 ) the detrital model assumes that calcic horizons form by solution, reprecipitation, and cementation of fragnitits of detrital $\mathrm{CaCO}_{3}$; and finally 6) the pedogenic model involves the formation of calcic horizons by soil-forming processes where dissolved $\mathrm{CaCO}_{3}$ is moved downward from the surface by infiltrating water and is precipitated deeper in the profile. Klappa (1983) favored pedogenic processes for accumulation of most calcic materials since calcic accumulations and soils have the following attributes in common: 1) on a megascopic scale $(\mathrm{km})$, both soils and calcic horizons are laterally extensive surface materials that occur on stable geomorphic surfaces; 2) soils and 
calcic horizons are conformable to the present-day topography; and 3) on a local scale $(\mathrm{cm})$ there is a vertical sequence of zonation in soils from the surface downward into unaltered parent material. The presence of a zone in a soil profile where weathering products (e.g., calcium carbonate) have accumulated would be consistent with soil-forming processes.

Because pedogenic processes probably represent the dominant mode of formation of calcic horizons (Reeves, 1976; Klappa, 1983) and because soils and paleosols of the Hanford and surrounding areas have been shown to be pedogenic in origin (Rasmussen, 1971; Foley, 1982; Gentry, 1984; McDonald, 1987a,b; Busacca, in press), the following discussion will concentrate on formation of calcic horizons in soils. For completeness, however, discussions will be included about the formation of calcic horizons in capillary and phreatic environments, which may have application to certain geomorphologic setuings at the Hanford Site.

\section{Geochemistry of $\mathrm{CaCO}_{3}$}

Dissolution and precipitation reactions. The basic genchemistry of $\mathrm{CaCO}_{3}$ solution and precipitation in soils and sediments has been discussed at length by a number of authors (e.g., Garrels and Christ, 1965; Lindsay, 1979; Bohn et al., 1985). Although varied environmental conditions may bring about the precipitation and accumulation of carbonate, the chemical reaction in systems open to the atmosphere is simply

$$
\mathrm{Ca}^{2+}+\mathrm{H}_{2} \mathrm{O}+\mathrm{CO}_{2}=\mathrm{CaCO}_{3}+2 \mathrm{H}^{+} .
$$

Alkaline conditions will favor the accumulation of $\mathrm{CaCO}_{3}$ by consuming $\mathrm{H}^{+}$and driving the reaction to the right; acidic conditions have the opposite effect. Increasing $\mathrm{pCO}_{2}$ (partial pressure of $\mathrm{CO}_{2}$ ) causes $\mathrm{CaCO}_{3}$ to react

$$
\mathrm{CaCO}_{3}+\mathrm{CO}_{2}+\mathrm{H}_{2} \mathrm{O}=\mathrm{Ca}^{2+}+2 \mathrm{HCO}_{3}^{-}
$$

so that $\mathrm{CaCO}_{3}$ dissolves with increasing $\mathrm{CO}_{2}$ concentration in the gaseous phase. According to Garrels and Christ (1965) the fundamental solution of carbonate equilibrium involves at most the activities of seven variables at constant temperature and pressure: $\mathrm{pCO}_{2}, \mathrm{H}_{2} \mathrm{CO}_{3}, \mathrm{HCO}_{3}^{-}, \mathrm{CO}_{3}^{-2}$, $\mathrm{H}^{+}, \mathrm{OH}^{-}, \mathrm{Ca}^{2+}$.

With the above equations in mind, v'e can qualitatively examine the dynamics of carbonate systems in soils and sediments. Dissolution of $\mathrm{CaCO}_{3}$ in soils is favored by conditions that drive equation (2) to the right, such as an increase in the amount of water (undersaturated with respect to $\mathrm{CaCO}_{3}$ ) passing through the soil, a situation that is more likely nearer the surface than at ciepth. In 
addition, a decrease in $\mathrm{pH}$, a decrease in ionic concentration in the soil solution (e.g., Ca $2+$ moving from solution onto exchange sites), and an increase in the $\mathrm{CO}_{2}$ content of the soil air are also contributing mechanisms for the dissolution of calcite. White (1988) proposed that $\mathrm{Ca}^{2}+$ cycling into above-ground biomass in grassland ecosystems, with deflation of $\mathrm{Ca}^{2}+$ in the ash following periodic fires would be sufficient to prevent $\mathrm{CaCO}_{3}$ from accumulating in soils of South Daknta. Humic acids produced by humus under developing vegetation may be responsible for accelerated leaching of $\mathrm{CaCO}_{3}$ on some dune sands on the Mediterranean coastal plain of Israel (Danin and Yaalon, 1982). In addition, the partial pressure of $\mathrm{CO}_{2}$ in soil air may be 10 to 1000 tirries its concentration in the atmosphere (Wood and Greenwood, 1971; Edwards, 1975; Reardon, et al., 1979; Wood and Petraitis, 1984). Such elevated concentrations in the soil are a direct result of the biotic components of the soil system, especially root and microbial respiration along with organic matter decomposition. In these zones, the dissolution of carbonates is probably driven by the high $\mathrm{pCO}_{2}$ values.

Precipitation of calcium carbonate, on the other hand, will occur under conditio..s that drive equation (1) to the right, such as a increase in $\mathrm{pH}$, a decrease in the partial pressure of $\mathrm{CO}_{2}$, increasing the ionic concentration to the point of saturation, either through continued solubilization of minerals or by decreasing the soil moisture content by evapotranspiration. Decreases in the $\mathrm{CO}_{2}$ content of the soil air may occur in response to assimilation of $\mathrm{CO}_{2}$ and $\mathrm{HCO}_{3}^{-}$plants during photosynthesis (Klappa, 1983).

In the near-surface environment, the most favored mechanism for precipitation of calcite from solutions containing $\mathrm{Ca}^{2+}$ and $\mathrm{HCO}_{3}^{-}$is evaporation of water until the solution is supersaturated with respect to calcite (Reeves, 1976; Klappa, 1983). If evaporation or transpiration is the dominant mechanism for calcite precipitation, then the position of the calcic horizon is related to the depth of effective leaching. This would not mean that all water movement stops at the level of carbonate precipitation, only that the water is no longer able to carry $\mathrm{CaCO}_{3}$ in solution. A similar situation was described by Stuart and Dixon (1973) where water failed to move across an abrupt textural break, which led to precipitation of calcite at the interface as soil water was removed by evapotranspiration. Stuart and Dixon further observed that concentrations of roots at such a physical barrier would hasten the rate of water removal and the rate of calcite precipitation. It appears that the physiological activities of the biota can significantly influence what may largely be an abiotic process. The distribution of roots will influence both the transpiration of water and the distribution of $\mathrm{CO}_{2}$ in the profile. In addition, preferential cementation of calcite around roots has been described by Klappa (1980). Klappa ascribed this phenomenon to removal of water by transpiration, or alternatively, root decay may induce calcite precipitation, with the location of the precipitate 
being determined largely by the distribution and amount of moisture in the rhizosphere. Calcite precipitation will tend to occur on surfaces that retain moisture as held water films on and between skeletal grains, root surfaces, fungal hyphae, and already precipitated calcite grains (Klappa, 1980).

The above discussion is related primarily to calcic horizons that are attributable to pedogenic processes. That is, settings in which there is a significant role for biota to play, and the calcite has accumulated by the downward leaching of calcium and bicarbonate ions from the upper soil horizons by infiltrating rainwater (Reeves, 1976). In some environments, however, geologists envision a strictly abiotic mechanism for precipitation of $\mathrm{CaCO}_{3}$. These non-pedogenic carbonate accumulations are believed to form at or near a water table that is close to the ground surface in regions of low rainfall and hich evaporative potential (Mann and Horowitz, 1979; Arakel, 1986). In such situations, groundwater solutions are concentrated to such an ex.tent that carbonate precipitates. Continued precipitation of calcite causes the older carbonate deposits to be forced upward toward the ground surface. This leads to a situation where the older carbonates are at the top of the carbonate deposit, and younger precipitates are at the bottom. This is the reverse of carbonate deposits in soils, where calcite precipitation grows from the bottom up, and the oldest deposits are at the bottom. Regardless of whether a carbonate accumulation is pedogenic or non-pedogenic, desiccation of a solution containing calcium and bicarbonate ions is a key geochemical process.

Isotope geochemistry. The dissolution and precipitation processes that lead to an accumulation of $\mathrm{CaCO}_{3}$ often lead to a change in the carbon and oxygen isotope composition of the secondary carbonates (Salomons and Mook, 1976; Magaritz and Amiel, 1980; Magaritz et al., 1981; Gardner, 1984; Dever et al., 1987). These changes occur because the isotopic composition of the secondary carbunates depends not only on the composition of the pre-existing carbonate from which it dissolved, but also on the temperature and the isotopic composition of the solution from which it preci) itates (Emrich et al., 1970; Magaritz et al., 1981).

In response to normal physicochemical processes, an equilibrium-based isotopic fractionation will occur between phases of the $\mathrm{CO}_{2}-\mathrm{H}_{2} \mathrm{O}-\mathrm{CaCO}_{3}$ system (Rabenhorst et al., 1984). There is also a kinetic fractionation that occurs during irreversible chemical reactions such as photosynthesis and evaporation (Craig, 1957; Walker et al., 1988). This means that in plants there is a discrimination against the heavy isotopes of carbon in the products of photosynthesis, which results in plants with different metabolic pathways having different proportions of $\mathrm{C}$ isotopes. Consequently, the organic $\mathrm{C}$ forms are much depleted in the heavy isotopes relative to carbonate $\mathrm{C}$ (Rabenhorst, et al., 1984). In water, evaporation favors removal of lighter isotopes of oxygen and 
enrichment of remaining water with heavier isotopes. The result is that carbonates precipitated from an evaporating sol'stion become progressively enriched in heavy oxygen isotopes.

As a result, the isotope geochemistry of carbon and oxygen have been used to test hypotheses about the origin and mechanism of formation of secondary carbonates in soils and sediments. Among those hypotheses that have been tested are: 1) the source of carbonate in the profile (eolian-dust influx vs. detrital material; Magaritz and Amiel, 1980; Rabenhorst et al., 1984); 2) the age sequence of a vertical profile of carbonates in the soil (Gardner, 1984; Schlesinger, 1985); 3) the separation of pedogenic from detrital carbonate (Magaritz et al, 1981; Rabenhorst et al., 1984); and 4) the role of evaporation in precipitation of $\mathrm{CaCO}_{3}$ (Gardner, 1984; Schlesinger, 1985; Dever et al., 1987). The citations above are meant only to illustrate how isotope geochemistry has been utilized. It shou!d be noted that results using this method may not always be conclusive. For example, Gardner (1984) arrived at the conclusion that evaporation was responsible for the precipitation of carbonate despite a constant $18 \mathrm{O} / 16 \mathrm{O}$ ratio with depth. Gardner hypothesized that the uniform oxygen isotope composition represented a record of average precipitation composition and hydrologic conditions during the period of soil profile development. In contrast, Schlesinger (1985) envisioned that a seasonal climatic pattern affected both soil $\mathrm{pCO}_{2}$ and soil water in the geochemical system. Schlesinger felt that during a period of drought, pedogenic carbonate may precipitate as water evaporates from the soil (enriching the remaining water with ${ }^{18} \mathrm{O}$ ). At the same time, however, $\mathrm{pCO}_{2}$ would decrease because of plant dormancy, allowing greater influence of the atmosphere (higher ${ }^{13} \mathrm{C}$ content). Thus, the precipitated carbonate would show simultaneous enrichment of heavy stable isotopes of carbon and oxygen, without allowing one to distinguish between a change in soil water or a change in $\mathrm{pCO}_{2}$ as the driving mechanism for calcite precipitation (Schlesinger, 1985). It is possible that the isotope geochemistry of carbonates in the natural analogs could be used for similar purposes, especially the demonstration of the source of the carbonate material and possibly the age sequence of soil carbonates or the role of evapotranspiration in calcite precipitation.

\section{Carbonate accumulations in soils and sediments}

Microscopy of Soil Carbonates. Much controversy has surrounded the origin of near-surface horizons enriched in calcium carbonate, in part hecause of the diverse backgrounds of investigators (soil scientists, geologists, engineers, hydrologists) and because of the several descriptive terminologies that have evolved. In recent years, however, theories involving soil-forming processes have dominated because of the large amount of evidence that has been gathered that is consistent with a pedogenic origin (Klappa, 1983). Micromorphology, the study of soil properties by microscopic methods, has been used by many investigators to discriminate between geogenic and 
pedogenic carbonates in modern and ancient soils and sediments (e.g., Klappa, 1983; Courty et al., 1985; Andrews, 1988; Sarkar, 1988; and Wright et al., 1988); to provide specific information on the mode of precipitation of different forms of calcite crystals, that is whether they originate by biogenic or inorganic means (e.g., Klappa, 1979, 1980; Wieder and Yaalon, 1982; Wright, 1984; Solomon and Walkden, 1985; Beier, 1987; Phillips and Self, 1987; Reheis, 1988); to interpret climates of origin and influence of climatic change during soil development (e.g., Sehgal and Stoops, 1972; Reheis, 1987), and to document the developmental stages of carbonate forms over time (Sehgal and Stoops, 1972; Bal, 1975; Reeves, 1976).

One of the main attributes of calcrete (the geologic term for accumulations of secondary carbonates in near-surface environments) is the complexity of types, patterns, and mutual relationships of processes that have been observed (Klappa, 1983). "The petrographic complexity of calcretes reflects the brief and intermittent operation of numezous genetic processes in the subaerial diagenetic environment, together with the uneven movement of fluids through the parent sediment" (Solomon and Walkden, 1985, p. 882). The complexity of micro- and macromorphologies of carbonates has meant that there has not always been agreement as to the probable origin of certain forms and features. Confirming the pedogenic origin of carbonate cements in natural analog soils may be important if the goal is to interpret past regimes of water movement and to make model simulations of the effect of pedogenic accumulations on water balance in barrier materials. Fortunately, many workers have sought criteria to differentiate "true" or pedogenic carbonate forms from those accumulations of other geologic origins (principally the differentiation of features formed in the subaerial upper vadose zone [pedogenic environment] from those formed in the subaqueous phreatic fresh or saline environment).

Following and modifying guidelines set by Brewer (1964), authors such as Blokhuis et al. (1968), Sehgal and Stoops (1972), Wieder and Yaalon (1974, 1982), Bal (1975), Bal and Buursin! (1976), Solomon and Walkden (1985), and Courty et al. (1985) have consistently reported at least four principal features that differentiate pedogenic carbonates from those formed in deeper vadose and phreatic zones. First, pedogenic carbonates tend to occur as micrite (calcite crystals $<4 \mu \mathrm{m}$ ) or microspar (calcite crystals $4-20 \mu \mathrm{m}$ ) cements because of rapid precipitation from soil solutions during stages of extreme desiccation. Micrite in particular tends to be brownish in color and is poorly resolved in transmitted light microscopy (Solomon and Walkden, 1985). In some soils, micrite and microspar apparently recrystallize to sparry calcite $(>20 \mu \mathrm{m})$ in nodules and larger masses at a late stage of development (Sehgal and Stoops, 1972). Badiozamani et al. (1977) performed laboratory precipitation experiments in sediments and found that the micromorphology of carbonates from their vadose (unsaturated and oxygenated) zone experiments 
matched closely those reported for pedogenic carbonates. Second, concentrations of carbonates in soils, such as nodules and soft masses, tend to have diffuse boundaries with the surrounding soil matrix and to have the same size and shape of matrix mineral grains as the enclosing soil because they were formed in place in the soil matrix material. Third, cutans of calcite commonly line tubular and irregular pores in the soil matrix, also indicating in situ formation. Fourth, carbonate cemerited root casts, called rhizoliths (Klappa, 1980), and animal burrows are common in pedogenic calcretes and attest to the presence of rooted plants before or during precipitation of calcium carbonate.

As described above, carbonates in soils and paleosols, particularly those in loess or gravels, of the Columbia Placeau area, have been demonstrated to be pedogenic in origin by many workers. In addition, carbonates in loess-derived paleosols exhibit the four principal features just described in microscopic thin section and scanning electron microscopy.

At least two reports have emphasized the dominant role of soil insects such as cicadas in creating soil packing or fabric arrangements along their burrows that become avenues for preferential cementation (Hugie and Passey, 1964; Bal and Buursink, 1976). Soils and paleosols in loess around the Hanford Site and arid parts of the Columbia Plateau are dominated by features of faunal burrows cemented by carbonates (Busacca, in press), which we consider a further attestation of a pedogenic origin.

The question of whether carbonates in soils dissolve and precipitate as a result of purely geochemical controls (i.e., ionic strength of soil solutions, $\mathrm{pCO}_{2}$, etc.), as a result of active or passive effects of soil organisms, or as a combined effect of the two has sparked debate and research. This question may be an important one to the use of natural analog soils because the current generation of simulation models are geochemical equilibrium models that do not account for biological interactions. Light microscopy and scanning electron microscopy have been used to address this question. Much of the discussion has centered on the origin of needle-fiber calcite (James, 1972), which generally has a diameter of $0.5-6 \mu \mathrm{m}$ and a length of up to $120 \mu \mathrm{m}$. The simpler and perhaps more traditional view has been that this form of calcite, which is common as a channel or pore fillings and in some soft masses in calcic soils, forms by extreme supersaturation of rapidly evaporating pore solutions (see, for example, James, 1972; Knox, 1977; Solomon and Walkden, 1985).

The alternative hypothesis that needle-fiber calcite and micrite form in soils as calcified organic filaments of fungi, algae, actinomycetes, and root hairs of vascular plants has gained many adherents in recent years. The following discussion is taken largely from Klappa (1979). Precipitation of calcite may apparently take place in the mucilagenous sheath that surrounds the cells of blue- 
green algae during their life in the soil; carbonates may also precipitate around living root hairs. Cells, hyphae, or mycelia si fungi and actinomycetes can act as templates for precipitation of carbonates soon after their death as decomposition creates voids in the cell walls, and remaining cell constituents create a chemical microenvironment that favors calcite precipitation. At a later stage, calcite crystals that had a biochemical origin may act as a substrate for the precipitation of more calcite by inorganic processes. Recent papers, including those by Klappa (1980), Wright (1984); Beier (1987), Phillips and Self (1987), and Andrews (1988) have cited the close association of these calcite forms with roots, root hairs, decaying organic matter, or root pores, or that the forms of the calcite mimic the cell structures from which they are thought to have formed. Phillips and Selî (1987) postulated that needle-fiber calcite forms within the hyphae of living fungi associated with mycorrhizal roots. They cited as evidence a study by Callot et al. (1985) in which needlefiber calcite was demonstrated to form within mycelial strands of basidiomycetes.

Because calcite in soils also occurs as much larger sparty crystals, for example in hard nodules, it seems likely either that micrite and needle-fiber calcite that is precipitated directly or indirectly by organic means is later recrystallized to the larger spar, or that inorganic processes of piecipitation are responsible for the spar seen in soils. It is also possible that organic and inorganic means of precipitation coexist, especially in light of the massive accumulations of carbonates in some extremely well-developed calcareous soils (e.g., Machette, 1985), but the balance of the two in a particular soil or setting cannot be estimated at this time.

In support of inorganic controls on some forms of carbonate precipitation is the observation of pedogenic calcite replacing quartz, feldspars, and andesite grains in calcic soils 120,000 years old and older (Reheis, 1988) and replacing tuffaceous sediments (Hay and Reeder, 1968). Replacement of original mineral grains by calcite may help to explain the observation that framework primary mineral grains in calcretes with $\mathrm{K}$ fabric (Gile et al., 1965; see discussion below) "float" in a matrix of secondary carbonates, that is, they do not touch adjacent framework grains as they would have in an original framework-supported sediment texture. Other workers have explained this fabric by noting evidence that crystallizing calcite can push apart parent mineral grains in a process called "displacive growth" (Watts, 1978, 1980).

Cathodoluminescence is a special technique of light microscopy that causes secondary calcites to luminesce and reveal details of íleir crystallization patterns not otherwise seen (Dorobek et al., 1987). Cathodoluminescence provides a means of analyzing the sequences of calcite precipitation in pores and of showing periods of precipitation and dissolution in the generation of complex cements in soils (e.g., Solomon and Walkden, 1985). In fact, Solornon and Walkden (1985) used the technique to discriminate details of the precipitation of needle-fiber calcite and micrite and 
concluded that they had formed as a result of inorganic processes of supersaturation of pore fluids during periods of rapid evaporation. The technique may have application to the study of natural analog soils if questions of pedogenic origin remain unanswered by other techniques or if a detailed history of precipitation and dissolution events is needed for carbonate cements.

Although there is general agreement that pedogenic carbonates translocate and accumulate in soils that have a seasonal or yearly soil moisture deficit (precipitation < evapotranspiration), micromorphologic properties have not been used to derive quantitative estimates of the climate of origin. Several research studies of note have used micromorphology to infer changes in soil climates during soil formation. Sehgal and Stoops (1972) recognized cutans of iron oxides intercalated with carbonate cutans, which they interpreted to be the result of periods of iron mobilization in soils that experienced an episodic rise of a shallow groundwater table. Allen and Goss (1974) and El-Tezhani et al. (1984) interpreted argillans (ped or grain coatings of translocated, oriented clay particles) that had been engulfed by secondary carbonates as evidence of a change in climate from wet to dry during soil development. Most recently, Reheis (1987) discovered as many as four bands of argillans alternating with five bands of carbonate precipitates in early Pleistocene alluvial soils that have experienced multiple glacial-interglacial climatic cycles from cool and moist to warm and dry. The principal means, then, that researchers have used to infer climatic change in calcic soils has been the association with other relatively persistent features in soils such as argillans. In paleosols of the Columbia Plateau region formed from loess, translocated or in-place iron oxides and clay in the matrix of cicada burrows that have been cemented by secondary carbonates suggest that some of the soils have been subjected to relatively wetter conditions early in their development and drier carbonate-accumulating conditions late in their development. These features have been seen principally in soils and paleosols in the geographic zone with a present-day mean annual precipitation of about $380-460 \mathrm{~mm}$. It is not known whether natural analog soils of the Hanford area that are less than about 12,000 years old display this polygenetic character as a result of Holocene climatic fluctuations.

One final consideration of micromorphology is whether carbonates in soils can be expected to follow a regular, definable sequence of accumulation on a micromorphologic scale, as has been expounded for field morphology (e.g., Gile et al., 1966). Researchers such as Sehgal and Stoops (1972) and Reeves (1976) have described sequences of accumulations as follows: Stage 1: microcrystalline calcite (micrite) is dispersed in the whole soil material; common calcite cutans line pores and channels; soft, diffuse nodules occur. Stage 2: Soft, diffuse nodules dominate, and the fabric of the soil matrix is dominated by the effects of the crystallization of the secondary microcrystalline calcite. Stage 3: Hard and compact nodules dominate, and the entire matrix is highly imuregnated 
by secondary calcite to form a K fabric (Gile et al., 1966); recrystallization forms spots of coarsegrained calcite. In contrast, Wieder and Yaalon (1982) argued that factors such as texture and porosity of parent material, carbonate and non-carbonate distribution of clay, bulk density, carbonate content of parent material, water regime, and others have such a profound influence on sites for nucleation, rate of nucleation, and complex genesis that several different forms and sequences of accumulations can be observed. This complexity may have implications for the expectation that the natural analog or barrier soils would go through characteristic and definable sequences of carbonate accumulation over time, particularly in terms of the impact of different forms of carbonates on porosity and permeabili.y.

Macroscopic profile features. The morphology of accumulations of calcite in soils and sediments is extremely varied and often complex, regardless of the riode of origin. Accumulations of calcite in the profile can consist of a single morphologic type or be composed of many morphologic types in various horizontal and vertical successions within the profile. Basic controls on forms seem to be parent material grain size and mineralogy; presence or absence of a limiting substrate such as hard bedrock, impervious strata, or laminar carbonate; sources of calcium carbonate either in the soil parent material or added as loess or salt spray; climate; and stage of profile development.

Calcium carbonate in soils and sediments can take the form of disseminated masses, filaments, nodules, oolites, pisolites, horizontal lamina, vertical seams, brecciated fragments, and fracture and vein fillings. Large-scale features such as buckle cracks and pseudo-anticlines also occur in indurated calcite accumulations (Gile, 1961; Reeves, 1976).

Disseminated carbonate consists of faint accumulaticns of clay-sized (micritic) calcite in the groundmass of non-calcareous parent material or as grain coatings and bridges on sand grains. Disseminated carbonate will often accentuate bedding in sediments. Filaments are formed by precipitation of calcite along active or abandoned root channels. This results in a fine network of white "pseudo-mycelia" ramifying througl the soil. It is not thought that filamentous forms provide any cementing action at this stage. Nodules can range in size from less than $2 \mathrm{~cm}$ to $30 \mathrm{~cm}$ in diameter, and they can be soft or hard but are internally structureless. They are most often subspherical, but vertically elongate forms also exist (Gile et al., 1966). In general, the smaller nodules are less lithified than the larger ones (Reeves, 1976). Oolites are defined as subspherical, generally hard masses of carbonate less than $2 \mathrm{~mm}$ in diameter formed by precipitation of successive thin laminae on a sand grain or other particle. Pisolites are defined as generally hard masses of subspherical carbonate g,eater than $2 \mathrm{~mm}$ in diameter formed by successive precipitation of thin laminae on sand grains, gravels, or pieces of indurated carbonate. They can range in size up to $30 \mathrm{~cm}$ (Hay and Reeder, 1968). Laminae occur where downward profile drainage is impaired 
due to plugging of profile porosity by other forms of carbonate, or where there is a shallow, impervious bedrock or other stratum. In these cases the drainage is forced into a lateral direction. Individual lamina are usually a $0.1 \mathrm{~mm}$ thick, to at most a few millimeters; they are often stacked, however, into plates (centimeters) and then into sheets (up to several meters thick) (Reeves, 1976).

Other macroscopic features include breccia, rhizomorphs, and pseudo-anticlines. Breccia are produced when lamina, plates, and larger pisolites and nodules are broken into angular fragments and then recemented. Brecciation and recementation may be a result of climatic change or desiccation (Reeves, 1976), root penetration (Klappa, 1979), or a consequence of displacive growth (increasing volume) of the carbonate as it accumulates in the profile (Watts, 1978). Rhizomorphs or rhizoliths (Klappa, 1980) are root casts in which the plant roots are calcified, giving indirect evidence of the vegetation that once existed. Pseudo-anticlines are local areas of extreme distortion in the carbonate accumulation that result in a structural feature with amplitude of several centimeters to several meters. The origin of these features is uncertain but expansion and contraction by cyclical wetting and drying (Reeves, 1976), displacive crystal growth (Watts, 1978), or slumping of underlying strata seem to be reasonable explanations.

Developmental sequences. The features described above refer only to features that may be seen in a soil profile. Gile $e t$ al. (1966) introduced the concept that there can be a morphologic sequence based on increasing amounts of carbonate and the changing physical characteristics of pedogenic calcite in soils over the time of soil development. This scheme was formulated after examination and study of calcic soils on a chronological sequence of alluvial terraces and fans along the Rio Grande River in New Mexico. This development sequence has been revised by Machette (1985) and used on soils throughout the desert southwest of the United States.

Briefly, the sequence proposed by Gile et al. (1966) divided the accumulation process into four stages. Slightly different paths are followed depending on whether the soil parent material is gravelly or non-gravelly. These paths converge in the last stage of development. Stage I in gravelly soils begins as a thin, soft, discontinuous accumulation of filaments and flakes of carbonate in the soil matrix, and thin discontinuous coatings on gravels. In non-gravelly soils, Stage I is characterized by a few filaments along root channels and coatings on sands or ped faces.

Stage II in gravels is characterized by continuously coated gravels and fine earth whitened somewhat by disseminated carbonate. Occasional areas of pebbles and fine earth will be cemented together. In non-gravelly soils, the carbonate begins to precipitate around sand grains and other nuclei to form nodules, oolites, or pisolites. The matrix is generally noncalcarcous to slightly calcarenus. 
Stage III in gravels contains many interpebble fillings, and nearly all skeletal grains are contin. uously coated with carbonate. This stage may also lead to complete plugging of interstices with carbonate so that cementation with carbonate is more or less continuous. On non-gravelly soils there are many nodules and internodular fillings, and practically the entire horizon is carbonate impregnated, and most skeletal grains are coated with carbonate. Nodules are commonly embedded in the horizon, suggesting a genetic relation to the previous stage. Horizons with characteristics of a Stage-III morphology in which the entire soil fabric is dominated by carbonates are the $\mathrm{K}$ horizon described by Gile et al. (1965).

The diagnostic features of a Stage-IV accumulation are an indurated horizon of nearly pure, roughly horizontal carbonate laminae and an underlying indurated, carbonate-plugged horizon like that of a Stage-III accumulation. This stage is the same for gravelly and non-gravelly soils. Accumulations of carbonate at this stage may be alternatively called petrocalcic horizons or calcrete.

Machette (1985) modified the sequence of Gile et al. (1966) to recognize two additional stages of carbonate accumulation. Stage IV of Gile et al. (1966) was proposed to the maximum degree of carbonate morphology and included all thickness of laminae. Machette, however, recognized more advance morphology in extremely old calcic horizons, particularly in pedogenic calcretes. He pro-. posed that Stage IV be limited to petrocalcic horizons with laminae less than $1 \mathrm{~cm}$ thick. In Stage $\mathrm{V}$, the laminae are thicker than $1 \mathrm{~cm}$ and, in some cases, there are thick, concentrically banded pisolitic structures. These pisolites commonly have cores of fragments of Stage IIl soil matrix or Stage IV laminae, suggesting that brecciation is an integral part of pisolith formation in soils.

Stage VI morphology is characterized by multiple episodes of brecciation and pisolith formation through relamination and recementation of breccia fragments. The resulting products are thick masses of pedogenic carbonate. Machette suggests that soils of Stage VI are the climax products of relatively continuous carbonate accumulation for over a million years.

Although the morphology of any calcic horizon is a function of the progressive accumulation of carbonate, and thus morphology may be indicative of relative age, correlation of similar pedogenic carbonate morphologies does not indicate similar ages. Gile et al. (1966) found that Stage IV morphologies (laminar accumulations) are formed faster on gravelly soils than on non-gravelly ones.

\section{Modeling Pedogenic Accumulations of Carbonate in SoIls}

Given the complexity of soil systems, models become convenient and often necessary devices to provide frameworks to guide investigations and simplify the assimilation of data. Models 
become a necessity in order to predict behavior or describe relationships between components of the soil system (Dijkerman, 1974; Smeck et al., 1983). Kline (1973) added that another function of models is to aid the development of experimentally testable hypotheses about either the future states of the system or effects of perturbations on the system.

The use of models becomes especially important in studying pedogenic processes in soils. The morphological properties of soils develop as a result of processes acting on parent materials through time (a dynamic system). Although there may only be a few processes that may be dominant at any one time, the long time scale and the number of variables involved makes it impractical, if not impossible, to observe changes-of-state through direct experimentation (Kline, 1973). The development of a model becomes obligatory.

The use of models in studies of pedogenesis is not new; however, previous efforts have been concentrated on functional or factorial models in which soil properties are related to external conditions, initial material or time (progress toward an equilibrium state; Smeck et al., 1983). The model of Simonson $(1959,1978)$, discussed previously, was one of the earliest attempts to view pedogenesis using a systems or process-response approach. It was, however, only a generalized conceptual scheme for organizing and studying soil-forming processes. More detailed approaches to applying systems concepts to mathematical modeling and simulation of pedogenesis have been given by Kline (1973).

One of the primary benefits from developing a mathematical model is that the system's structure and behavior are explicitly expressed in the form of mathematical equations. Thus, intuitive beliefs are formalized and subject to scrutiny and comparison.

One of the earliest attempts at linking the depth of carbonate accumulation to climatic variables was by Jenny and Leonard (1939). Using a functional, factorial appror h, they found a distinct trend between increasing depth to the upper surface of the carbonate horizon and increasing mean annual precipitation. Arkley (1963) refined these concepts in order to take into account the water holding capacity (WHC) of soils and to allow for the effects of evapotranspiration on the net arwount of water available to wet the soil profile on an annual cycle. The excess of precipitation over evapotranspiration Arkley called the "leaching index."

In 1985, two systems models appeared that simulated the transportation and accumulation of $\mathrm{CaCO}_{3}$ in soils (CALDEP: Marion et al., 1985; CALSOIL: McFadden and Tinsley, 1985; Mayer, 1986). Both of these models are compartment models that utilize easily obtained soil parameters, 
some form of climate simulation, and chemical thermodynamic relationships to calculate the flux of $\mathrm{CaCO}_{3}$ through a soil profile. They are both written to run on personal computers.

Both models were built to simulate conditions in the desert southwest of the United States and were validated by comparing simulation output to field data selected from soils of the region. Marion et al. (1985) used the mean depth of the first $\mathrm{CaCO}_{3}$ bulge in the soil profile to compare field data to the simulation model output. The CALSOIL model was validated by demonstrating the close fit between simulated distributions and actual distributions for selected soils (Mayer et al., 1988).

One of the more significant differences between the two models is the method by which climate is simulated. CALDEP utilizes a stochastic precipitation model that emphasizes the importance of individual storms to fluxes of carbonate through the profile. CALSOIL continues the use of Arkley's leaching index, and thus, does not explicitly consider the role of extreme events in carbonate transport.

Another process given more attention in CALDEP than CALSOIL is the fcedback effect of carbonate accumulation upon the WHC of the soil. CALDEP includes a subroutine that decreases the compartment porosity as carbonate accumulates, which in turn, is used to recalculate the WHC of the compartment. The program even allows for plugging pores when the bulk density reaches a critical value $\left(2 \mathrm{~g} \mathrm{~cm}^{-3}\right)$. CALSOIL has no such dynamic interaction between soil parameters and carbonate accumulation.

Perhaps the one advantage that CALSOIL has over CALDEP is speed. CALSOLL, when simulating climate on a yearly basis, can simulate 12,000 years in approximately 5 minutes on a personal computer (based upon the personal experience of the authors). CALDEP, however, takes approximately 75 minutes to simulate 100 years (Marion et al., 1985), because climate is simulated on a daily basis. Thus, to simulate 12,000 years would take approximately 150 hours on a personal computer.

Both McFadden (McFadden and Tinsley, 1985; Mayer et al., 1988) and Marion et al. (1985) utilized their models to evaluate the influence of a changing climate on the formation of calcic horizons. McFadden found good agreement between the distribution of carbonates in Holocene-aged 
soils and the simulation model predictions of same by assuming that the present climate approximates the entire Holocene. Marion did not find such close agreement using current climatic conditions. Marion found it necessary to utilize a cool-wet climate scenario to get agreement.

Both of the models presented above are relatively simple in their approach. Water movement occurs between compartments only after field capacity of the higher one is reached; solute fluxes and water flow are in a downward direction only. In both, the modeling of $\mathrm{pCO}_{2}$ contents of the soil profile is static, and neither model incorporates competitive ion effects into the carbonate geochemistry model. In addition, both models assurne a relatively stable land surface with no possibility for sediment erosion or deposition. Consequently, these models are only good first approximations.

\section{ISSUES AND LIMITATIONS ASSOCIATED WITH STUDY OF ANALOG SOILS AND WITH SIMULATION MODELING OF PEDOGENIC CARBONATE}

Two approaches have been identified to aid in the assessment and prediction of the performance of protective barriers: natural analogs and simulation modeling. Natural analogs provide information about processes affecting barrier performance that cannot be fully explored through modeling or field or laboratory experimentation because of the long periods of time involved $(10,000$ years). There are two major goals associated with the use of either natural analogs or simulation modeling of pedogenic carbonate accumulation in soils at the Hanford Site as a barrier performance assessment tool: 1) to reconstruct Holocene water movement from the distribution of pedogenic carbonate, and 2) to simulate the feedback effect of carbonate accumulation on soil hydraulic properties and unsaturated recharge in the proposed protective barrier designs. To deal with the issues and limitations associated with either of these objectives, we will pose them as questions: "Can we reconstruct the movement of water during the Holocene-based upon the distribution of pedogenic carbonate?" and "Is it possible to simulate the feedback effect of carbonate accumulations on soil hydraulic properties?" Before answering these questions, however, we will review the components necessary to answer these questions, namely 1) the characteristics of the natural analogs and their likely origin, and 2) the attributes of exising models, including a preliminary sensitivity analysis of CALSOL. 


\section{Issues Associated with Applying Simulation Models to soils at the HANFORD SITE}

Natural analog soils of the Hanford area: simple or complex?

One approach the barriers program has proposed to use to better understand the long-term performance of layered earthen barriers is the study of natural analogs to the barriers, that is, actual soils of the Hanford region that are similar in their physical attributes to proposed barrier designs and similar in age to the projected design life of the barriers (Adams and Wing, 1986; Wing, 1988).

Natural analog soils may provide a means to interpret past histories of soil water movement; may provide input soil property data for models that assess barrier performance if barriers acquire properties like those of the analog soils over time; and may provide a means to test or validate simulation models of carbonate accumulation. Some of the positive attributes of these potential "natural laboratory" soils and some of the drawbacks of the soils or limitations of our knowledge will be discussed in this section. Much of the information comes from observations of one of us (Busacca, in press) over the past seven years in research across the Columbia Plateau supplemented by referenced sources of published and unpublished information as indicated. Documentation can be provided for unpublished materials if needed at the appropriate time.

Many of the soils of the region that could be chosen for study as natural analogs have formed in fine-over-coarse layered sediments. Those that have formed in eolian sediments that overlie alluvium of the last major episode of cataclysmic floods in the Channeled Scabland (Baker and Bunker, 1985) have been forming for approximately 13,000 years as a first approximation of age (Busacca, in press). Initial reconnaissance of the Hanford area demonstrated the existence of many variations on the layered as well as massive soil parent material theme for snils that might serve as natural analogs. For these reasons, properly selected natural analog soils may give an excellent indication of the pedogenic (soil-formed) properties that layered barrier materials could be expected to have acquired at the end of their extended period of performance $(10,000$ years). This is evidence that could not be obtained by field experiments or computer simulations because of the extraordinary time frame mandated for barrier performance relative to that of a single human life.

Some of the most common and widespread layered soils that might be suitable as natural analogs are those that consist of a bed of loess (windblown silty sediment) over thinly bedded slackwater Touchet sediments (alternating beds of sandy and silty sediment from quietwater deposition of cataclysmic floods), or over sand or gravel from the higher energy deposits of 
floods. The layer or bed of loess that overlies flood sediments (referred to here as post-scablandflood loess or post-flood loess) range" commonly from less than 50 to more than $200 \mathrm{~cm}$ thick (see Figs. 1,2; McDonald, 1987a,b; Busacca, in press). Eolian or dune sand, from reworking of flood deposits since about 13,000 years, is another sediment and soil parent material. It covers much of the east-central Pasco Basin (Bjornstad et al., 1987) as active or stabilized dunes. Soils in these materials tend to be deep and weakly developed because of their dune origin, youth, and coarse texture; however, layered natural analog soils that consist of a mantle of eolian sand over flood sand or gravel do exist at some sites in the Hanford area.

In the soils of the Pasco Basin and environs, the principal pedologic feature that could indicate past regimes of water movement in "post-flood soils" and also affect hydraulic properties of the soils is the precipitation of horizons of secondary calcium carbonate. Within the geographic zone encompassing approximately up to $400 \mathrm{~mm}$ of present day mean annual precipitation $(2 \mathrm{x}$ Hanford), research has not provided evidence for argillic or incipient argillic (strong cambic) horizons in the post-flood soils or in paleosols dating to about 50,000 years (McDonald, 1987b). Horizons of silt accumulation also have not been recognized in this area, and horizons of significant salt accumulation are not known to occur in soils that would likely serve as analogs for barrier designs (although they do occur, for example, in soils with a high water table in the Yakima Valley). For these reasons, we have not considered clay or silt translocation or salt accumulations further at this time in considering potential analog characteristics.

The soils characterized by McDonald (1987a) at the weighing lysimeter facility, Arid Lands Eculogy Reserve, are typical examples of potential analog soils that have formed in loess of varia. ble thickness that overlies stratified sand and silt from cataclysmic flooding (Figs. 1, 2). Soil developmer thas apparently been strongly influenced by the textural interface between loess and flood sediments. Slightly darkened topsoil (A horizon or ochric epipedon) and cambic (Bw) horizons have formed in the mantle of loess. The topsoil is too light in color and low in organic matter to qualify as a mollic epipedon, principally because of the arid conditions that limit plant growth and in turn humus formation. A cambic horizon (Soil Survey Staff, 1975) is a subsurface horizon of slight weathering, release of iron oxides, development of soil structure, and leaching of carbonates. The cambic horizon in these soils have slightly higher color chromas than horizons above or below them and have weak prismatic and moderate subangular blocky siil structure. Secondary pedogenic carbonates have been precipitated in the slackwater sediments below the textural discontinuity to form calcic (Bk) or near-calcic horizons (Fig. 2). The morphology and 
SAGEBRUSH SITE

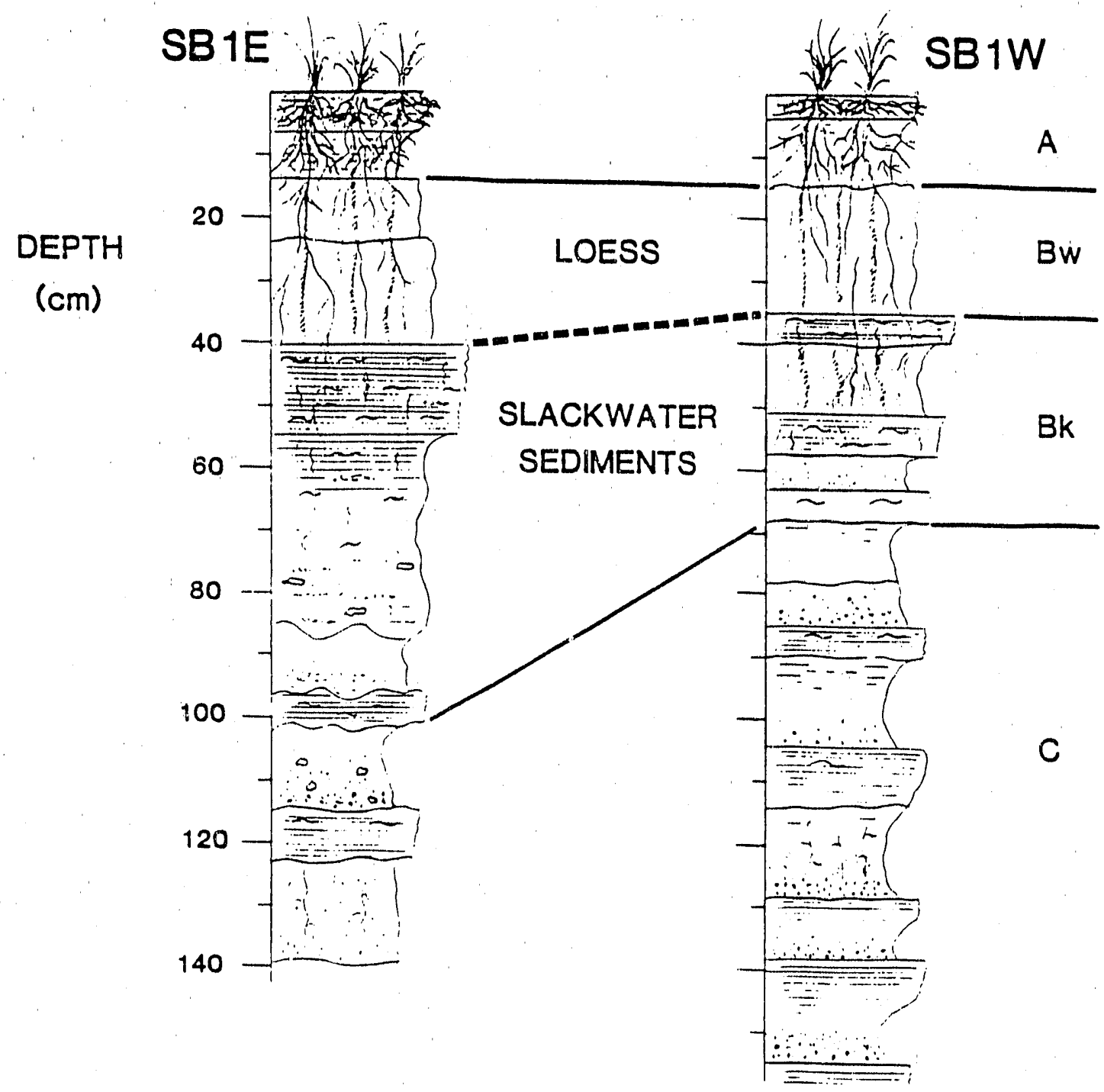

SYMBOLS

SOIL STRUCTURE

granular
platy
prismatic

SEDIMENTS

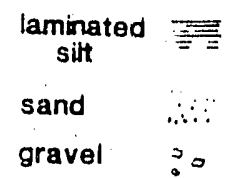

CARBONATES

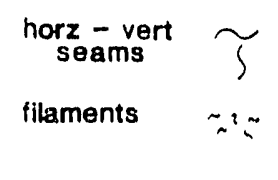

Figure 1. Schematic drawing of profile morphology at the sagebrush site of the weighing lysimeter facility, Arid Lands Ecology Reserve. Post-flood loess extends from the surface of both soils to about $40 \mathrm{~cm}$; below that depth are slackwater sediments from late Wisconsin cataclysmic floods. From McDonald (1987a). 

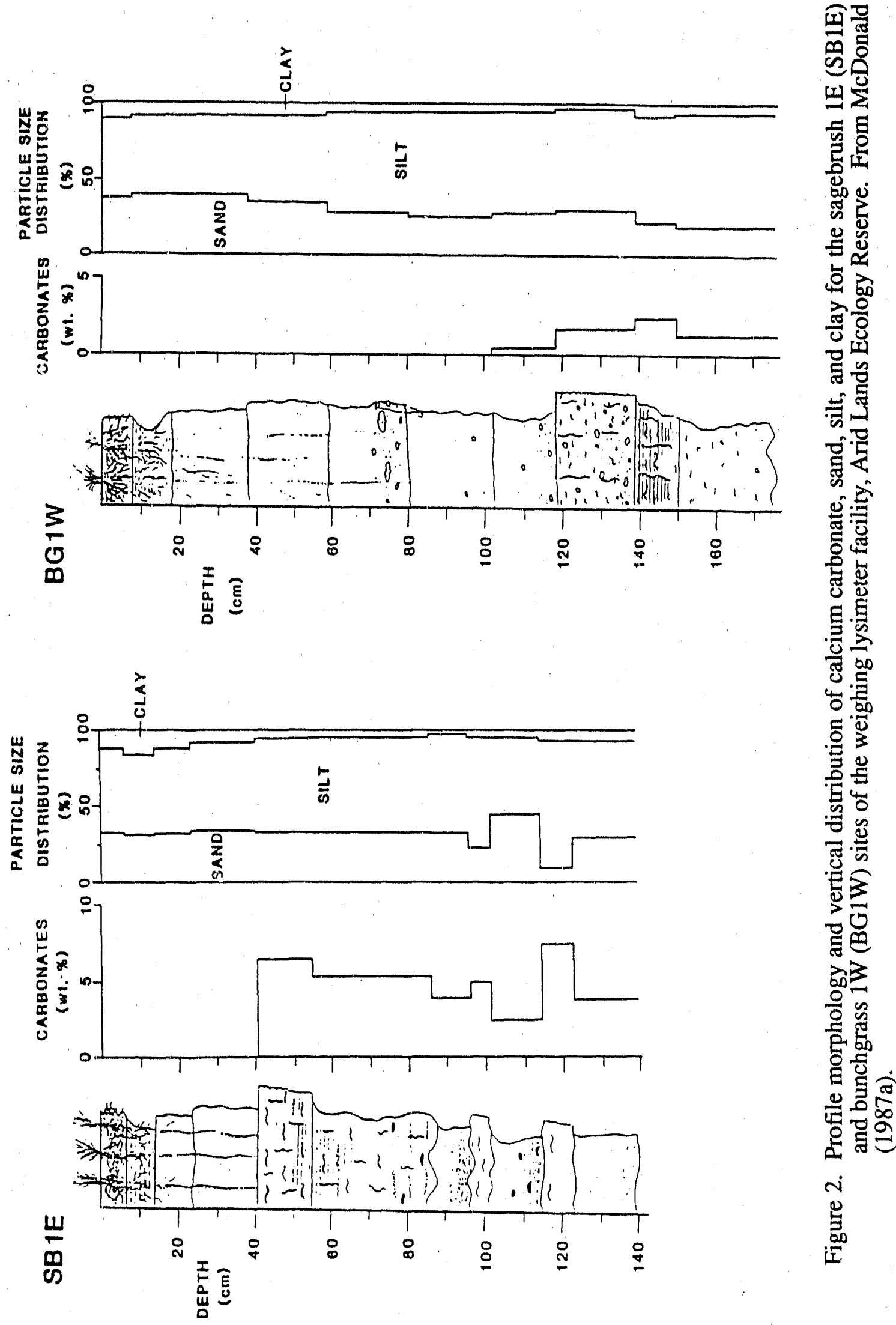

峁 
other properties of these soils is characteristic of the Xerollic Camborthid subgroup in Soil Taxonomy. Camborthids consist of soils of the Aridisol order (ids) that have a simple profile morphology (orth) consisting of a weakly developed A horizon over a cambic horizon (camb). In addition, Camborthids have no free carbonates above $18 \mathrm{~cm}$. The shallower soils at the site (e.g., SB1E, Fig. 2) are correlated to the Sagemoor soil series and the deeper (e.g., BG1W, Fig. 2) are correlated to the Warden series. Both soils are very widespread on the Columbia Plateau; both are coarse-silty, mixed, mesic Xerollic Camborthids. Layers of volcanic ash that would undoubtedly occur in some exposures of potential natural analog soils, along with the deductions that follow from past studies of similar soils in the region (e.g., McDonald, 1987a,b ; Busacca, in press ), can provide critical limiting ages for flood sediments, dune sand, and loess. They may provide key information about periods of soil development also, but this is more problematical, as will be discussed below. Tephras are direct, correlatable time markers where present, and methods exist ts "fingerprint" them by chemical and petrogrophic means (Foley, 1982; Nelstead, 1988).

Three layers of volcanic ash (tephra) are associated with the late Wisconsin flood deposits and post-flood loess: Mount St. Helens set S tephra (ca. 13,000 years; Mullineaux, 1986; Mullineaux et al., 1978), Glacier Peak layers G and B (ca. 11-12,000 years; Mehringer et al., 1984), and Mount Mazama (ca. 7,000 years; Bacon, 1983). The set $S$ tephra is found in the upper parts of late Wisconsin flood sediments or in basal parts of the post-flood loess in areas of the Channeled Scabland, the Pasco Basin, and adjacent valleys (McDonald, 1987b; Nelstead, 1988; Bjornstad, et al., (1987); Busacca, in press). Glacier Peak tephra is more rare in the Hanford area but has been found in loess, slopewash, and ponds (Bjornstad et al., 1987), on the northern plateau in the Wilber-Banks Lake area in loess, and in the area of Lind Coulee in flood slackwater sediments (Moody, 1978). Mazama tephra has been found in post-flood loess throughout the Plateau area (e.g., Foley, 1982; Bjornstad et al., 1987) and from dune sand, alluvium, slopewash, and ponds (Bjornstad et al., 1987).

The presence of time markers in an analog soil, however, does not mean that we know all that we would like about the history of that soil for the purposes of reconstructing past history, past climates, or for validating simulation models. Having a time marker such as Mount St. Helens set $S$ at or near the interface between flood sediments and loess in an analog soil indicates that loess deposition began at that site about 12 or 13,000 years ago. The rate at which loess accumulated from 13,000 years to the present is not known with any certainty. Did it accumulate at a constant rate over the entire time? Did most of it accumulate in the first 2,000 years? At this time, the evidence suggests that loess deposition occurred as a series of pulses, and that soil-forming processes were imprinted differentially on the silt loam sediment as the land surface rose during deposition. 
This is because two or even three weak calcic horizons have been observed in the upper slackwater materials and loess of some potential analog soils (e.g., Fig. 2). Alternatively, more than one calcic horizon could form in a single loess layer if, for example, an episode of climatic warming or drying caused carbonates to be precipitated at sequentially higher positions in the profile. Active soil development during deposition of loess considerably complicates any attempt to isolate and determine the relationship between past soil water movement and calcic horizons because of the interaction and "competition" between deposition, soil development, and climate change. Erosion, either episodic or constant, has a similar complicating effect.

Can we learn enough about the races of loess deposition and erosion (or dune movement if sandy soils are considered) through the late Pleistocene and Holocene to be able to separate the effects of loess deposition from any change due to climate? The position of the Mazama tephra in analog soils would give further information on rates if it could be recognized by field or microscopic methods because it was deposited almost exactly in the middle of the time from 13,000 years ago to the present. Thermoluminescence (Berger, 1988) is still in a validation phase as a dating technique for Quaternary sediments, but it potentially offers the best possible means to derive quantitative estimates of deposition rates. This is because sediments such as loess are dated directly by collecting and analyzing small volumes of material; sequential increments of loess potentially could be sampled and dated in analog soils. This technique, along with cathodoluminescence analysis of generations of carbonate cements, may also find application if uncertainty exists over whether some of the loess or carbonates in an analog profile could be from older episodes of soil development.

A related issue is that neither CALSOIL nor CALDEP presently allows for deposition or erosion during soil development. Both assume that a fixed thickness of parent material exists at soilforming time zero, and that this thickness does not change during a simulation. Any model developed for conditions at the Hanford Site and surrounding area would need to have this feature to accurately simulate Holocene carbonate accumulations. Such a model needs this capability also so that erosion from or eolian deposition to the barriers during the period of operation could be simulated and the effects evaluated.

Other uncertainties in the use of analog soils center on the properties of the parent materials at soil forming time zero. Key among these is the initial content of calcium carbonate available in the parent material to be dissolved and reprecipitated. Our preliminary sensitivity analysis of the current generation of the CALSOIL program shows that final carbonate distributions are strongly affected by initial content of $\mathrm{CaCO}_{3}$ (see below). The initial content of carbonate in loess parent materials appears to have ranged from two to perhaps as high as 10 percent depending on texture 
and proximity to sediment sources such as the Walla Walla and Touchet valleys. This is based on measurements on "unaltered loess" deeper in the stratigraphic section (McDonald, 1987b).

Coarser textured loess proximal to source areas have contents in the high end of this range, and the content decreases in a general way with distance and fining, but the regional pattern of carbonate content within any loess bed is likely to have been complex. Accurate assessment of initial carbonate content will be difficult because of the complex effects of soil development in a rising landscape. This means, for example, that carbonates could be leached from an increment of sediment during the time it is closest to the surface and is acting as an A horizon. At a later time, secondary carbonates could be precipitated in the same increment when it is in a profile position to act as a calcic $\mathrm{B}$ horizon. The process of overlap of different soil development processes in the same material on an accreting or eroding landscape has been called "soil welding" (Ruhe and Olson, 1980). Microscopic or other methods might be needed to try to identify and quantify transported (parent) grains of calcium carbonate in parent materials. Little or no information is available at this time on parent content of carbonates in sands or gravels from floods.

A final question regarding the use of analog soils is: how sensitive are soils to recording changes in processes or changes in the intensity of processes? That is, for example, what threshold value of climatic change maintained for what period of time is necessary before the effecs of the change would be recorded permanently in the features of the soil profile? For example, if a calcic horizon were to form at $100 \mathrm{~cm}$ under a certain climate, how much drier would the climate have to become before the zone of precipitation of carbonates would move measurably higher in the profile, and for what time would the new climate have to persist for an observable new calcic horizon to form? Conversely, if a strong calcic horizon were to develop during a long period of stable climate, and it greatly reduced permeability at that level, would a shift to a much wetter climate be recorded by the development of a new calcic zone at a greater depth, or would the feedback effect of the reduced permeability cause carbonates to continue to precipitate at the original depth? Simulation models can help us answer questions like these, but if a model is developed based on the properties of analog soils, the same model could be of questionable value in testing such questions.

One of the most valuable reasons to examine and characterize analog soils may be to measure the hydraulic properties associated with measured quantities of secondary carbonates in calcic horizons. This information would be used to build feedback effects into carbonate simulation models and to provide input data on changing hydraulic properties to the unsaturated flow model to allow the model to respond dynamically to a calcic horizon (or other pedogenic feature) as it would form in barrier materials over time. It is not known at this time but could be measured whether different 
hydraulic properties are associated with the same quantities of carbonate if it is in different forms (plates, seams, nodules, filaments, disseminated).

\section{MOdel ATTRIBUtes}

\section{Existing Simulation Models}

Similarities between CALDEP and CALSOIL. As was stated previously, two models exist at present that attempt to simulate the accumulation of pedogenic carbonate: CALSOIL and CALDEP. To reiterate: both models are compartment models, with each compartment assigned a finite thickness making it correspond to an actual position in the soil column. These compartments do not directly correspond to soil horizons with physical attributes such as structure and color, but serve to simulate the textural and chemical stratification in the profile. Both models employ simple geochemical approaches that incorporate effects of soil temperature and $\mathrm{CO}_{2}$ on calcite solubility; neither model, however, incorporates more sophisticated routines to account for other physicochemical processes that may influence calcite solubility (e.g., gypsum solubility, ionpairing, ion-exchange). Both models assume that calcite dissolution is rapid relative to water movement and do not allow for particle size effects of detrital carbonate.

Water flow is simulated in both models as saturated flow; consequently, both water and carbonate move from a compartment to a lower compartment only when the WHC of the first compartment is exceeded. Finally, although both models allow for influx of carbonate dust ( a major source of $\mathrm{Ca}^{2+}$ in the southwest U.S.), they both assume a stable geomorphic landscape and thus do not allow for loess deposition or surface erosion.

Dissimilarities between CALSOIL and CALDEP. Despite the similarities, there are significant differences. Perhaps the most critical to model performance is the use of a stochastic rainfall model in CALDEP. Such an approach allows CALDEP to accurately simulate both the mean and variance of annual precipitation for selected sites. In addition, the stochastic approach to an event-based process model allows for the testing of hypotheses about the impact of extreme storm events on solute fluxes. CALSOIL, on the other hand, depends on average annual leaching indices to determine the quantity of water available for solute transport.

The method by which each model calculates evapotranspiration is another important difference, especially given the role of evapotranspiration in causing calcite precipitation. CALDEP calculates actual evapotranspiration in three steps. First, potential evapotranspiration is calculated using Thornthwaite's equation (Thornthwaite, 1948). Second, potential evapotranspiration is converted to pan evaporation using derived, empirical equations, and third, actual evapotranspiration is 
calculated as a function of soil moisture and pan evaporation. CALSOIL has the option to calculate potential evapotranspiration using either Thornthwaite's equation or by Papadakis's method (cited in Mayer et al., 1988), either of which can be used to directly estimate the amount of water available for leaching. Water lost by evapotranspiration from the soil compartments is also estimated differently. CALDEP extracts water first from the surface horizon and then progressively from deeper compartments. CALSOIL attempts to simulate the effect of plant roots and thermal insulation by using an arbitrary index that is proportional to the amount of water taken from a compartment to determine the depths from which water is extracted by evapotranspiration.

Sensitivity analysis of CALSOIL

CALSOIL was validated by its authors by comparing carbonate distributions in wellcharacterized soil with the synthetic distributions from the model (McFadden and Tinsley, 1985; Mayer et al., 1988). These comparisons showed a correspondence between the model and real soils. A sensitivity analysis is another alternative for model validation, since such an analysis tests the model's response to perturbations of driving variables, parameters, and initial conditions. Knowledge of conditions to which the model is sensitive enables a better understanding of the model itself (MacNeil et al., 1985). Identification of mode: parameters that are sensitive (or insensitive) suggests that the corresponding part of the natural system may also be sensitive (or insensitive). If the modeled portion of the natural system is known to be sensitive (or insensitive), a similar observation of model sensitivity may also serve as a qualitative validation of the model (MacNeil et al., 1985).

No sensitivity analysis has been published for either CALSOIL or CALDEP. Given the uncertainty about the relative importance of various mechanisms of calcite precipitation in soils, as well as the specific role of these mechanisms in soils at the Hanford Site, a sensitivity analysis can serve to point out specific limitations of a model and what kinds of information about soil parameters is needed. Accordingly, a preliminary sensitivity analysis for CALSOLL was performed.

1 copy of CALSOIL was obtained from its author, Larry Mayer. The program was written in BASIC and is available in versions for Microsoft MS-DOS ${ }^{\circledR}$ or Apple Macintosh ${ }^{\circledR}$ operating systems. This sensitivity analysis was done using an Apple Macintosh ${ }^{\circledR}$ SE. The program was revised (by Craig Hunter) to improve its function and to ease the difficulty associated with data input and output.

The model was initialized using best available data or estimates for climate and soils at the Hanford Site (McDonald, !987a; Gee et al., 1989). The initial conditions used for the simulation 
were as follows. The soil profile consisted of 20 compartments that were $10 \mathrm{~cm}$ thick. The duration of the simulation was 12,000 years. There was no carbonate influx as either dust or dissolved in the precipitation. Profile characteristics consisted of $150 \mathrm{~cm}$ of soil with the following attributes: silt loam texture ( $38 \%$ sand, $50 \%$ silt, $12 \%$ clay), WHC $=1.91 \mathrm{~cm}^{3} 10 \mathrm{~cm}^{-3}$, bulk density = $1.37 \mathrm{~g} \mathrm{~cm}^{-3}$, porosity $=50 \%$, and initial carbonate content was input at $5 \%$ on a weight basis. Other input parameters included $\mathrm{pCO}_{2}$, soil temperature, and the $\mathrm{E}-\mathrm{T}$ index. We varied these compartment parameters with depth in an attempt to simulate the presence of plant roots and insulating properties of soils. The leaching index $(7.08 \mathrm{~cm}$ ) was determined (by the program) using climate data from the Hanford Meteorological Station. The remaining $50 \mathrm{~cm}$ of the profile differed from the top in its texture $\left(100 \%\right.$ sand), WHC $\left(0.01 \mathrm{~cm}^{3} 10 \mathrm{~cm}^{-3}\right)$, and initial carbonate content $(0 \%)$.

The carbonate distribution predicted by CALSOIL using these inputs is shown in Fig. 3. Using these inputs, CALSOIL predicts that the carbonate maximum will occur at $40 \mathrm{~cm}$ and will contain $17 \%$ carbonate. With no annual influx of carbonate, the carbonate maximum represents the redistribution of carbonate from the upper compartments to the compartment at $40 \mathrm{~cm}$. Because the water flow is modeled as saturated flow, according to the model, this is the point below which water does not move.

To examine the effect of a capillary barrier on carbonate accumulation, the interface between the silt loam soil and the sand was raised to $20 \mathrm{~cm}$. This had the effect of decreasing the total soil WHC. The resulting distribution is shown in Fig. 4. Raising the sand interface results in a very irregular distribution, but the maximum is at approximately $100-120 \mathrm{~cm}$. According to this simulation, a textural break, as envisioned for the protective barriers, would not inhibit either the movement of water or carbonate movement. These results are not unexpected given the reliance on saturated flow by the CALSOIL model. They are, however, at variance with our knowledge and observations about natural soil systems. For example, the soils at the weighing lysimeter facility examined by McDonald (1987a) exhibit horizons of secondary carbonate that are apparently completely controlled by depth to textural interface and independent of climate. Stuart and Dixon (1973) have also observed the common occurrence of carbonate accumulations at the junction between finer textured materials and sand or gravel. Indeed, the premise upon which the protective barriers are based is that water will not move across a textural break, as simulated. In this case, it would seem that the use of saturated flow is not an accurate representation of natural soils. It is likely that soils in arid regions seldom remain at field capacity, and thus, rainfall in real soils 
Depth, cm

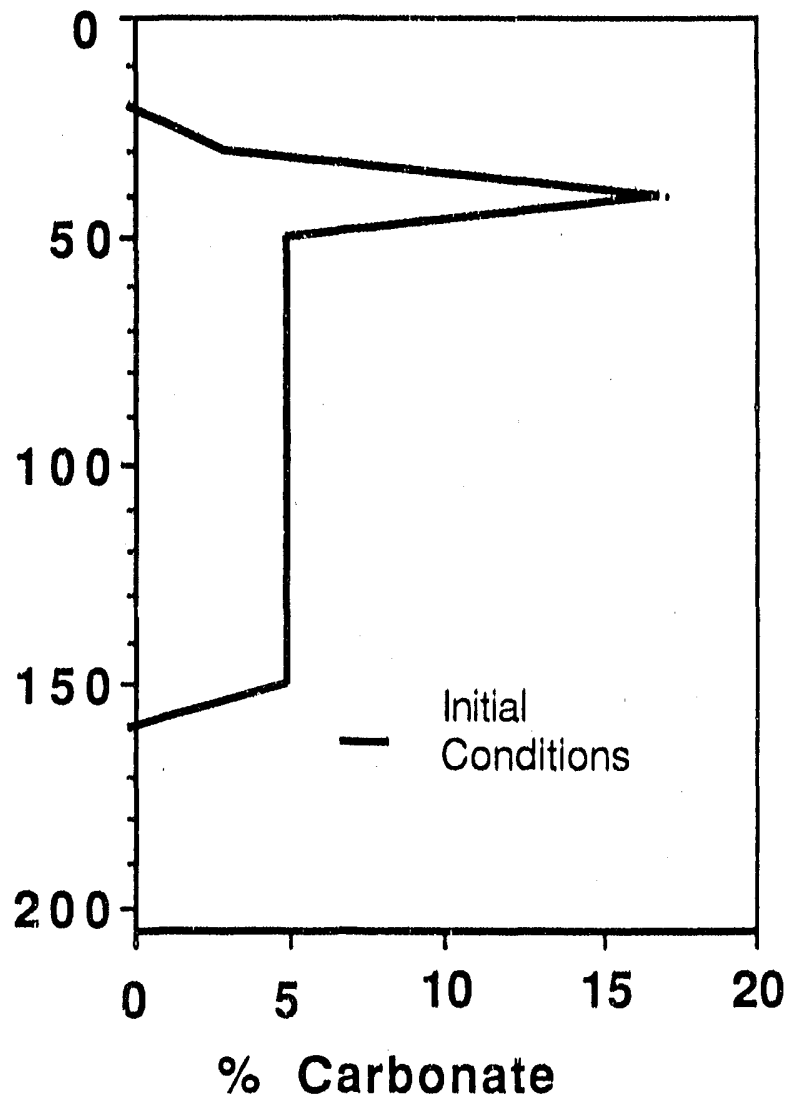

Figure 3. Synthetic distribution of carbonate using initial conditions outlined.

analogs) is insufficient to move water into the coarse-textured layer. This is probably sufficient to invalidate the ability of the current generation of the CALSOIL model to assess the performance of the protective barriers.

Other input parameters that had a significant effect on the carbonate distribution included changing the carbonate influx, changing the WHC of the soil material, and increasing the rainfall. Changing the carbonate influx only affected the amount of carbonate that accumulated at $40 \mathrm{~cm}$, but did not change the maximum depth of accumulation. This is not unexpected because the maximum depth of accumulation depends upon water movement. Accordingly, changing the WHC and the 


\section{Depth, cm}

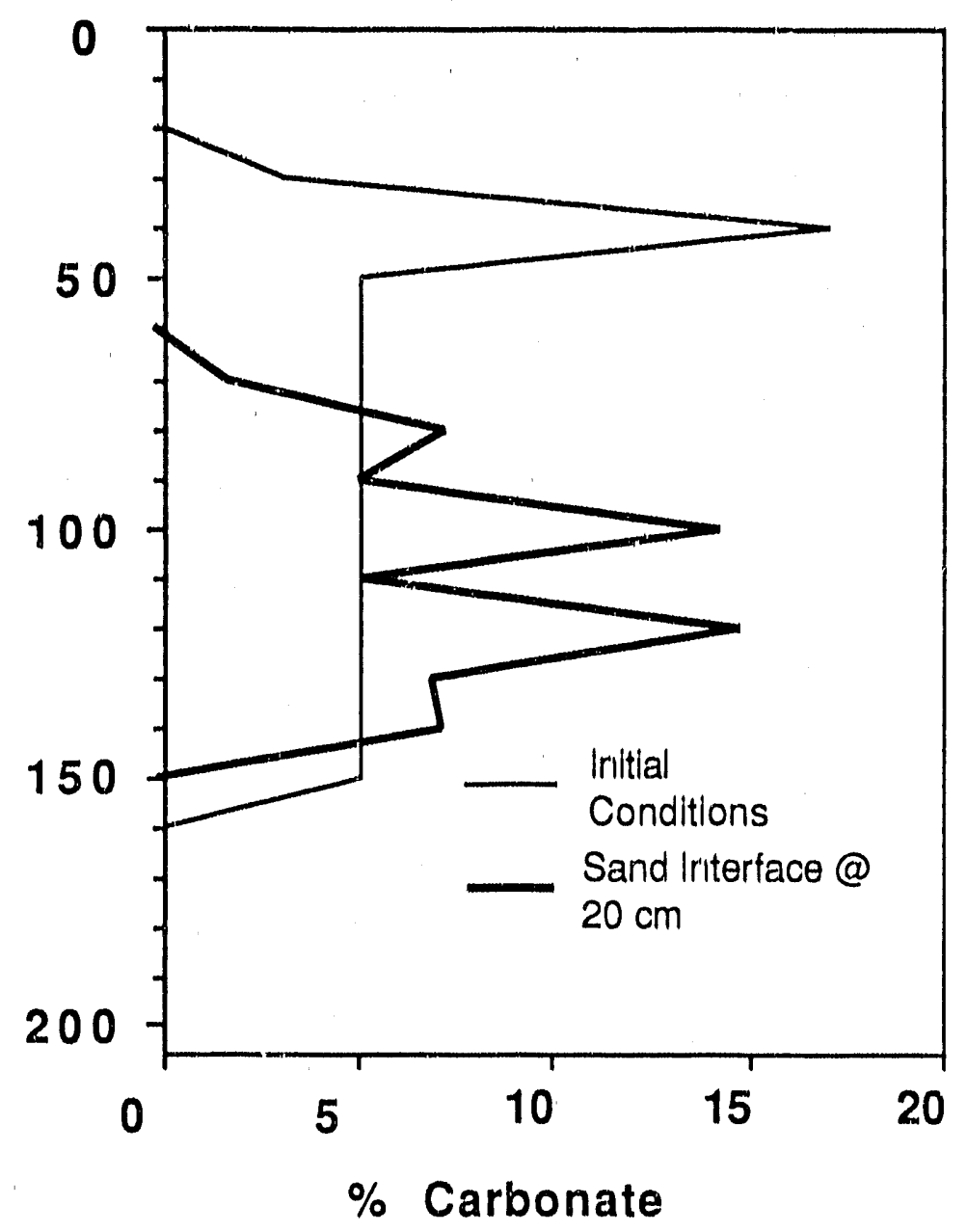

Figure 4. Synthetic carbonate distribution comparing the simulation using the initial conditions with the distribution using a sand interface at $20 \mathrm{~cm}$.

amount of rainfall both affected the maximum depth of leaching. Increasing the WHC of the silt loam material by $30 \%$ raised the depth of maximum accumulation to $30 \mathrm{~cm}$, while decreasing the WHC by $30 \%$ lowered the depth of maximum accumulation to $50 \mathrm{~cm}$. Increasing the rainfall to $2 \mathrm{x}$ the present climate caused the depth of maximum carbonate accumulation to deepen to $80 \mathrm{~cm}$.

Changing other input parameters such as the air temperature, soil temperature, or $\mathrm{E}-\mathrm{T}$ index had minimel effect on either amount of carbonate accumulated or the depth to which it moved 
relative to the inital values. Changing the initial carbonate content values in each compartment only influenced the amount accumulated, but not the depth to which it moved.

Thus, it would seen that the model i: driven by and is most sensitive to the amount of water entering the system and the mechanism by which water moves through the soil. Neither CALSOIL nor CALDEP differ in their approach to water movement in soils, and therefore, do not appear to simulate in an effective martner the conditions expected in the protective barriers. To simulate carbonate movement in texturally contrasting, layered soil systems, another approach will be needed to accurately predict the movement of water and solutes.

\section{MODELING CARBONATES AS A PERFORMANCE ASSESSMENT TOOL}

We have previously posed as questions the major goals for this project: "Can we reconstruct the movement of water during the Holocene based upon the distribution of pedogenic carbonate?" and "Is it possible to simulate the feedback effect of carbonate accurnulations on soil hydraulic p sperties?" Based upon our theoretical knowledge about the geochemistry of carbonate systems and our practical experience with soils, the answer to both of these questions is a qualified yes. The answer is qualified for several reasons. First and foremost is that presence of calcic horizons is evidence that water became saturated (with respect to calcite) at that point, not that water stopped moving completely. If saturated flow is the dominant mechanism for water and solute movement, then it would be possible to state that water would stop moving at the point of of calcite accumulation until there was either an increase in the amount of precipitation, or a decrease in the WHC of the soil compartment. In arid and semi-arid areas, however, water movement in soils is predominantly by unsaturated flow. In this case, some water is expected to move deeper in the profile than predicted using saturated flow. How much water and how far it moves are unknown. To answer these questions, a more sophisticated treatment of waste movement in soils is needed than is currently provided by either CALDEP or CALSOIL. The numerical techniques to accomplish this task are available (Campbell, 1985), but the size of the task to scale these techniques into a model that would adequately represent pedogenic processes over long periods of time is unknown. It is also possible that other approaches could be taken. An alternative might be to use water movement profiles generated by a more sophisticated and computationally intensive program (UNSAT-H, for example) and then calculate the carbonate fluxes in the model profile. Such an approach may be less dynamic, but easier to implement.

Another point to consider is that currently there is little or no information available on the effect of accumulating carbonates in soil profiles on the hydraulic properties of soil. Is there a critical threshold below which carbonate accumulation has no effect on hydraulic properties? Does it 
depend on both the amount and its morphological form? Must the calcic horizon become indurated before there is an appreciable effect? The answers to these question's are unknown; while research is required to adequately answer them, this should not pose an insurmountable obstacle to building a model that adequately simulates the feedbacks between carbonate accumulation and hydraulic properties of the soil.

If a decision is made to build a model that accurately simulates the pedogenic accumulation of carbonate in the proposed protective barriers, that model should probably have the following components or attributes:

- The model should allow for the addition (or loss) of both carbonate and noncarbonate particulate material to the soil surface;

- Transport of both solutes and water should respond to the physical properties of the soil material; and

- There must be a feedback loop that accurately simulates the effect of carbonate on soil hydraulic properties.

A problem arises, however, in validating any model that is built to simulate conditions at the Hanford Site. As was stated previously, CALSOIL and CALDEP were validated by comparing synthetic carbonate distributions to naturally occurring soils. The primary objective in the development of these two models was to evaluate different climatic scenarios that might lead to the development of the observed soils. The soil-landscape relationships of the soils studied in the southwest U.S. by Marion et al. (1985) and McFadden (1985) are different from those at the Hanford Site. The study soils in the desert Southwest exist in large part on stable alluvial fans and have not had significant additions or losses of material with the exception of carbonates. The situation at the Hanford Site is quite different. Since the deposition of slackwater sediments near the end of the last glaciation, there has been a continuous or episodic addition of loess, which has caused the aggradation of the soil profile. Consequently, the depth of pr sfile features we observe today is the result of continuous additions over the past 13,000 years plus the action of the soilforming processes, and not just the soil-forming process as is the case in the Southwest. In addition, we must also deal with the question of a changing climate. It is not possible to solve for two unknowns with one equation (the model), thus the natural analogs cannot serve both to build a model and as validation for the model. It may be possible to validate the model using a full sensitivity analysis, but the uncertainty associated with this is unknown. 


\section{SUMMARY AND RECOMMENDATION}

\section{SUMMARY}

To briefly summarize, pedogenic indicators of soil water movement exist. Those that are most significant in arid and semi-arid environments include clay, silt, and soluble salts, including calcium carbonate. Based on existing studies of soils at the Hanford Site and the personal knowledge of the authors about soil characteristics in eastern Washington, the accumulation of $\mathrm{CaCO}_{3}$ is the most likely pedogenic indicator of water movement at the Hanford Site. Calcium carbonate is a common feature in soils and sediments of arid and semi-arid environments, and pedogenic processes probably represent the dominant mode of formation.

The geochemistry of $\mathrm{CaCO}_{3}$ is relatively simple and depends upon the availability of $\mathrm{Ca}^{2+}$, $\mathrm{pCO}_{2}$, and water. Two mechanisms have been identified as being primarily responsible for carbonate precipitation in soils: evapotranspiration and degassing of $\mathrm{CO}_{2}$. Thus, it is likely there are biotic and abiotic components influencing the precipitation of carbonate in soil. The relative importance of both of these processes has been demonstrated using techniques such as isotope geochemistry, micromorphology, and cathodoluminescence. The amount and morphology of carbonates in soils are also a function of the progressive accumulation of carbonate over time.

Two systems models (CALDEP and CALSOIL) that simulate the accumulation of $\mathrm{CaCO}_{3}$ were examined. Although there are functional differences between the two models, especially in the modeling of climate and the feedbacks between carbonate accumulation and soil porosity, both models utilize saturated flow as the mechanism for water and solute transport. By performing a sensitivity analysis, we were able to demonstrate that CALSOIL is most sensitive to soil and cli. mate parameters that influence water movement such as WHC and rainfall. We concluded that neither the CALSOIL nor the CALDEP model effectively simulates the conditions expected in the protective barriers.

As a result of our exploration of the literature and simulation models along with our observations about soils at the Hanford Site, we have identified several issues and limitations associated with the use of natural analogs and simulation modeling in support of the goals of this project: 1) to reconstruct Holocene water movement from the distribution of carbonates in layered sediments as an analog of future long-term water movement in protective barriers, and 2) to simulate the feedback effect of carborate accumulation on soil hydraulic properties and unsaturated recharge in proposed protective barrier designs. 
- It is probably prudent to abundon the concept that the depth at which carbonates precipitate is the depth below which no unsaturated recharge occurs. The presence of a calcic horizon only indicates that the soil solution became supersaturated with respect to carbonate not that water flow stopped completely.

- Based on the characteristics of the soils at the Hanford Site, we know that carbonates have accumulated in soils during the Holocene. We also know that under climates of today (not radically different from most of the Holocene) that unsaturated flow has been demonstrated (Gee et al., 1989) through most of the depth of the proposed protective barriers. We would conclude then that unsaturated flow probably occurred during the formation of calcic horizons during the Holocene.

- The natural analogs cannot be used for the basis of any model that is developed and also as a means of validating that model if it is also to be used to test different climatic scenarios. Independent verification of Holocene climatic scenarios may need to come from other phases of the natural analogs research. Sensitivity analysis may also provide an alternative means of model validation.

- The natural analogs can be used to measure hydraulic properties of calcic horizons and compare them to noncalcic soils to determine the likely influence of carbonate accumulations on water movement in the protective barriers.

- The natural analogs do not directly answer the recharge question. Based on the natural analogs, it is likely that calcic horizons will form in the protective barriers. The question remains, however, how much, when, and where the carbonate will accumulate. A model could provide predictions for these questions. How big a model is needed, though, is unknown and would require further investigation.

\section{RECOMMENDATION}

There exists enough uncertainty at this tine about the effect of carbonate accumulations on the hydraulic properties in protective barrier designs that we recommend that work continue at least through the project planning phase. This would allow us to further explore issues such as what level of complexity is needed in a model to predict carbonate accumulations in soil. We feel there is a primary research need to know how much impact carbonate accumulation has on hydraulic properties of soils. Such information is not currently available in the literature. We propose that during the project planning phase, a work plan for research be prepared to relate proposed research to the issues outlined above. Appendix A contains an issues hierarchy and study plan outline. 


\section{LITERATURE CITED}

Adams, M. R., and Wing, N. R., 1986. Protective barrier and warning marker system development plan. RHO-RE-PL-35P, Westinghouse Hanford Company, Richland, WA.

Aguilar, J., Guardiola, J. L., Barahona, E., Dorronsoro, C., and Santos, F., 1983. Clay illuviation in calcareous soils, p. 541-550, in P. Bullock and C. P. Murphy (eds.), Soil Micromorphology, Volume 2: Soil Genesis. A. B. Academic Publishers, Berkhamsted, United Kingdom.

Ailcn, B. L., and Goss, D. W., 1974. Micromorphology of paleosols from the semi-arid southern high plains of Texas, p. 511-525, in G. K. Rutherford (ed.), Soil Microscopy: proceedings of the 4th international working meeting on soil micromorphology, Limestone Press, Kingston, Ontario.

Andrews, J., 1988. Soil-zone microfabrics in calcrete and in desiccation cracks from the upperJurassic Purbeck Formation of Dorset. Geological Journal, 23: 261-270.

Arakel, A. V., 1986. Evolution of calcrete in palaeodrainages of the Lake Napperby area, central Australia. Palaeogeography, Palaeoclimatology, Palaeoecology, 54: 283-303.

Arkley, R. J., 1963. Calculation of carbonate and water movement in soil from climatic data. Soil Science, 96: 239-248.

Bacon, C. R., 1983. Eruptive history of Mount Mazama and Crater Lake Caldera, Cascade Range, USA Journal of Volcanology and Geothernal Research, 18: 57-115.

Badiozamani, K., Mackenzie, F. T., and Thorstenson, D. C., 1977. Experimental carbonate cementation: Salinity, temperature and vadose-phreatic effects. Journal of Sedimentary Petrology, 47: 529-542.

Baker, V. R., and Bunker, R. C., 1985. Cataclysmic late Pleistocene glacial Lake Missoula: A review. Quaternary Science Reviews, 4:1-41.

Bal, L., 1975. Carbonate in Soil. A Theoretical Consideration on, and Proposal for its Analysis. I. Crystic, Calcic, and Fibrons Plasmic Fabric. Netherlands J. of Agric. Science 23: 18-35.

Bal, L., and Buursink, J., 1976. An Incept'sol formed in calcareous loess on the 'Dast-i-Esan Top' plain in North Afghanistan. Fabric, mineral and trace element analysis. Netherlands Journal of Agricultural Science, 24: 17-42.

Bartelli, L. J., and Odell, R. T., 1960. Laboratory studies and genesis of a clay-enriched horizon in the lowest part of the solum of some Brunizem and gray-brown Podzolic soils in Illinois. Soil Science Society of America Proceedings, 24: 390-395.

Beier, J. A., 1987. Petrographic and geochemical analysis of caliche profiles in a Bahamian Pleistocene dune. Sedimentology, 34: 991-998.

Berger, G. W., 1988. Dating quaternary events by luminescence. Geological Society of America Special Paper 227: 13-50, Boulder, CO. 
Birkeland, P. W., 1984. Soils and Geomorphology. Oxford University Press, New York, NY.

Bjornstad, B. N., Fecht, K. R., and Tallman, A. M., 1987. Quaternary stratigraphy of the Pasco Basin Area, RHO-BW-SA-563A, Rockwell Hanford Operations, Richland, WA.

Blokhuis, W. A., Pape, Th., and Slager, S., 1968. Morphology and distribution of carbonate in some Vertisols of the Sudan. Geoderma, 2: 173-200.

Bohn, H. L., McNeal, B. L., and O'Connor, G. A., 1985. Soil Chemistry (2nd ed.) John Wiley \& Sons, New York, NY.

Brewer, R., 1964. Fabric and Mineral Analysis of Soils. John Wiley \& Sons, New York, NY.

Bunting, B. T., and Christensen, L., 1978. Micromorphology of calcareous crusts from the Canadian high Arctic. Geologiska Föreningens i Stockholm Förhandlingar, 100: 361-367.

Burns, S. F., 1982. Silt translocation in alpine soils. Agronomy abstracts, annual meeting, Soil Science Society of America, Anaheim, CA.

Busacca, A. J. (in press). Loess deposits and soils of the Palouse and vicinity, in V. R. Baker et al., The Columbia Plateau, Ch. 3, in R. B. Morrison (ed.), Quaternary Non-Glacial Geology of the Conterminous United States. Geological Society of America Decade of North American Geology Vol. K-2.

Callot, G., Guyon, A., and Mousain, D., 1985. Inter-relations entre aiguillesde calcite et hyphes mycéliens. Agronomie, 5: 209-216.

Campbell, G. S., 1985. Soil physics with BASIC: Transport models for soil-plant systems. Elsevier Science Publishers, Amsterdam, The Netherlands.

Courty, M. A., Dhir, P., and Raghavan, H., 1985. Microfabrics of calcium carbonate accumulations in arid soils of western India. Soil Micromorphology, in proceedings of the seventh international work meeting on soil micromorphology, Paris, France, pp. 227-234.

Craig, H., 1957. Isotopic standards for carbon and oxygen and correction factors for mass-spectroscopic analysis of carbon dioxide. Geochimica et Cosmochimica Acta, 12: 133-149.

Danin, A., and Yaalon, D. H., 1982. Silt plus clay sedimentation and decalcification during plant succession in sands of the Mediterranean coastal plain of Israel. Israel Journal of Earth Sciences, 31: 101-109.

Dever, L., Fontes, J. Ch., and Riché, G., 1987. Isotopic approach to calcite dissolution and precipitation in soils under semi-arid conditions. Chemical Geology (Isotope Geosciences Section), 66: 307-314.

Dijkerman, J. C., 1974. Pedology as a science: The role of data, models and theories in the study of natural soil systems. Geoderma, 11: 73-93. 
Dorobek, S. L., Read, J. F, Niemann, J. M., Pong, T. C., and Haralick, R. M., 1987. Image analysis of cathodoluminescent-zoned calcite cements. Journal of Sedimentary Petrology, 57: 766-770.

Duchaufour, P., 1982. Pedology. (English translation by T. R. Paton). George Allen \& Unwin, London.

Edwards, N. T., 1975. Effects of temperature and moisture on carbon dioxide evolution in a mixed deciduous forest floor. Soil Science Society of America Proceedings, 39: 361-365.

El-Tezhani, M. S., Gradusov, B. P., Rubilina, N. Ye., and Chizhikova, N. P., 1984. Chemical and mineral composition of the finely dispersed component and microstructure of some soils in Sudan. Soviet Soil Science, 16: 75-81.

Emrich, K., Ehhalt, D. H., and Vogel, J. C., 1970. Carbon isotope fractionation during the precipitation of calcium carbonate. Earth and Planetary Science Letters, 8: 363-371.

Fanning, D. S., and Fanning, M. C. B., 1989. Soil: morphology, genesis and classification. John Wiley \& Sons, New York, NY.

Foley, L. L., 1982. Quaternary chronology of the Palouse loess near Washtucna, eastern Washington. M.S. Thesis, Western Washington University, Bellingham, WA. 137 p.

Forman, S. L., and Miller, G. H., 1984. Time-dependent soil morphologies and pedogenic processes on raised beaches, Bröggerhalvöya, Spitsbergen, Svalbard Archipelago. Arctic and Alpine Research, 16: 381-394.

Fullerton, S., and Pawluk, S., 1987. The role of seasonal salt and water fluxes in the genesis of solonetzic B horizons. Canadian Journal of Soil Science, 67: 719-730.

Gardner, L. R., 1984. Carbon and oxygen isotope composition of pedogenetic $\mathrm{CaCO}_{3}$ from soil profiles in Nevada and New Mexico, U.S.A. Isotope Geoscience, 2: 55-73.

Garrels, R. M., and Christ, C. L., 1965. Solutions, minerals, and equilibria. Freeman, Cooper \& Co., San Francisco, CA.

Gee, G. W., Kirkham, R. R., Downs, J. L., and Campbell, M. D., 1989. The field lysimeter test facility (FLTF) at the Hanford Site: Installation and initial tests. PNL-6810. Pacific Northwest Laboratory, Richland, WA.

Gentry, H. R., 1984. Soil survey of Grant County, Washington. U. S. Department of Agriculture, Soil Conservation Service, U.S. Government Printing Office, Washington, D.C.

Gile, L. H., 1961. A classification of ca horizons in soils of a desert region, Dona Ana County, New Mexico. Soil Science Society of America Proceedings, 25: 52-61.

Gile, L. H., Peterson, F. F., and Grossman, R. B., 1965. The K horizon: A master soil horizon of carbonate accumulation. Soil Science, 99: 74-82. 
Gile, L. H., Peterson, F. F., and Grossman, R. B., 1966. Morphological and genetic sequences of carbonate accumulation in desert soils. Soil Science, 101: 347-360.

Goss, D. W., Smith, S. J., and Stewart, B. A., 1973. Movement of added clay through calcareous materials. Geoderma, 9: 97-103.

Hassan, F. A., and Ghaibeh, A. S., 1977. Evaporation and salt movement in soils in the presence of water table. Soil Science Society of America Journal, 41: 470-478.

Hay, R. L., and Reeder, R. J., 1968. Calcretes of Olduvai Gorge and the Ndolanya Beds of northern Tanzania. Sedimentology, 25: 649-677.

Hugie, V. K., and Passey, H. B., 1963. Cicadas and their effect upon soil genesis in certain soils in southern Idaho, northern Utah, and northeastern Nevada. Soil Science Society of America Proceedings, 27: 78-82.

James, N. P, 1972. Holocene and Pleistocene calcareous crust (caliche) profiles: Criteria for subaerial exposure. Journal of Sedimentary Petrology, 42: 817-836.

Jenny, H., and Leonard, C. C., 1939. Functional relationships between soil properties and rainfall. Soil Science, 38: 363-381.

Kittr:-k, J. A., 1970. Synthesis of kaolinite at $25^{\circ} \mathrm{C}$ and 1 atm. Clays and Clay Minerals, 18: 261-267.

Klappa, C. F., 1979. Calcified filaments in Quaternary calcretes: Organo-mineral interactions in the subaerial vadose environment. Journal of Sedimentary Petrology, 49: 955-968.

Klappa, C. F., 1979. Comment on "Displacive calcite: Evidence from the recent and ancient calcretes." Geology, 6: 699-703.

Klappa, C. F., 1980. Rhizoliths in terrestrial carbonates: Classification, recognition, genesis and significance. Sedimentology, 27: 613-629.

Klappa, C. F., 1983. A process-response model for the formation of pedogenic calcretes, p. 211 220 , in R. C. L. Wilson (ed.), Residual deposits: Surface related weathering processes and materials. Geological Society of London Special Publication No. 11, Blackwell Scientific Publications, Oxford, England.

Kline, J. R., 1973. Mathematical simulation of soil-plant relationships and soil genesis. Soil Science, 115: 240-249.

Knox, G. J., 1977. Caliche profile formation, Saldanha Bay (South Africa). Sedimentology, 24: 657-674.

Kubiena, W. L., 1938. Micropedology. Collegiate Press, Ames, IA.

Lindsay, W. L., 1979. Chemical Equilibria in Soils. John Wiley \& Sons, New York., NY. 
Locke, W. W., and Mabee, S. B., 1979. Fine particle migration in coarse-grained Arctic soils. Agronomy Abstracts, annual meeting, Soil Science Society of America, Fort Collins, CO.

Machette, M. N., 1985. Calcic soils of the southwestern United States, p. 1-21, in D. L. Weide (ed.), Soils and Quaternary Geology of the Southwestern United States. Geological Society of America Special Paper No. 203, Fort Collins, CO.

MacNeil, M. D., Skiles, J. W., and Hanson, J. D., 1985. Sensitivity analysis of a general rangeland model. Ecological Modelling, 29: 57-76.

Magaritz, M., and Amiel, A. J., 1980. Calcium carbonate in calcareous soil from Jordan Valley, Israel: Its origin revealed by the stable isotope method. Soil Science Society of America Journal, 44: 1059-1062.

Magaritz, M., Kaufman, A., and Yaalon, D. H., 1981. Calcium carbonate nodules in soils: ${ }^{18} \mathrm{O} / 16 \mathrm{O},{ }^{13} \mathrm{O} /{ }^{12} \mathrm{O}$, and ${ }^{14} \mathrm{C}$ contents. Geoderma, 25: 157-172.

Mahjoory, R. A., 1979. The nature and genesis of some salt-affected soils in Iran. Soil Science Society of America Journal, 43: 1019-1024.

Mann, A. W., and Horwitz, R. C., 1979. Groundwater calcrete deposits in Australia: Some observations from Western Australia. Journal of the Geological Society of Australia, 26: 293-303.

Marion, G. M., Schlesinger, W. H., and Fonteyn, P. J., 1985. CALDEP: A regional model for soil $\mathrm{CaCO}_{3}$ (caliche) deposition in southwestern deserts. Soil Science, 139: 468-481.

Mayer, L., 1986. The distribution of calcium carbonate in soil: A computer simulation using program CALSOIL. U.S. Geological Survey Open-File Report 86-155.

Mayer, L., McFadden, L. D., and Harden, J. W., 1988. Distribution of calcium carbonate in desert soils: A model. Geology, 16: 303-306.

McDonald, E. V., 1987a. Soil characterization of the weighing lysimeter sites: Arid lands ecology laboratory field studies. Report prepared for Pacific Northwest Laboratory, Richland, WA.

McDonald, E. V., 1987b. Correlation and interpretation of the stratigraphy of the Palouse loess of Eastern Washington. M.S. Thesis, Washington State University, Pullman, WA. 218 p.

McFadden, L. D., and Tinsley, J. C., 1985. Rate and depth of pedogenic-carbonate accumulation in soils: Formulation and testing of a compartment model, p. 23-41 in D. L. Weide (ed.), Soils and Quaternary Geology of the Southwestern United States. Geological Society of America Special Paper No. 203, Boulder, CO.

McKeague, J. A., and St. Arnaud, R. J,, 1969. Pedotranslocation: Eluviation-illuviation in soils during the Quaternary. Soil Science, 107: 428-434.

Mehringer, P. J., Jr., Sheppard, J. C., and Foit, F. F., Jr., 1984. The age of Glacier Peak tephra in west-central Montana. Quaternary Research, 21:36-41. 
Moody, U. L., 1978. Microstratigraphy, paleoecology, and tephrochronology of the Lind Coulee site, central Washington. Ph. D. Thesis, Washington State University, Pullman, WA. 273 p.

Mullineaux, D. R., 1986. Summary of pre-1980 tephra-fall deposits erupted from Mount St. Helens, Wasnington State, U. S. A. Bulletin of Volcanology, 48: 17-26.

Mullineaux, D. R., Wilcox, R. E., Ebaugh, W. F., Fryxell, R., and Rubin, M., 1978. Age of the last major scabland flood of the Columbia Plateau in eastern Washington. Quaternary Research, 10:171-180.

Nelstead, K. T., 1988. Correlation of tephra layers in the Palouse loess. M. S. Thesis, Washington State Univesity, Pullman, WA. 80 p.

Phillips, S. E., and P. G. Self, 1987. Morphology, crystallography, and origin of needle-fibre calcite in Quaternary pedogenic calcretes of South Australia. Australian Journal of Soil Research, 25: 429-444.

Rabenhorst, M. C., Wilding, L. P., and West, L. T., 1984. Identification of pedogenic carbonates using stable carbon isotope and microfabric analyses. Soil Science Society of America Journal, 48: 125-132.

Rasmussen, J. J., 1971. Soil survey of Benton County area, Washington. U. S. Department of Agriculture, Soil Conservation Service, U.S. Government Printing Office, Washington, D.C.

Reardon, E. J., Allison, G. B., and Fritz, P., 1979. Seasonal chemical and isotopic variations of soil $\mathrm{CO}_{2}$ at Trout Creek, Ontario. Journal of Hydrology, 43: 355-371.

Reeves, Jr., C. C., 1976. Caliche: Origin, classification, morphology and uses. Estacado Books, Lubbock, TX.

Reheis, M. C., 1987. Climatic implications of alternating clay and carbonate formation in semiarid soils of south-central Montana. Quaternary Research, 27: 270-282.

Reheis, M. C., 1988. Pedogenic replacement of aluminosilicate grains by $\mathrm{CaCO}_{3}$ in Ustollic Haplargids, south-central Montana, U. S. A. Geoderma, 41: 243-261.

Ruhe, R. V., and Olson, C. G, 1980. Soil welding. Soil Science, 130:132-139.

Salomons, W., and Mook, W. G., 1976. Isotope geochemistry of carbonate dissolution and reprecipitation in soils. Soil Science, 122: 15-24.

Sarkar, S., 1988. Petrology of caliche-derived peloidal calcirudite/calcarenite in the late-Triassic Maleri Formation of the Pranhita-Godavari Valley, South India. Sedimentary Geology, 55: 263-282.

Schlesinger, W. H., 1985. The formation of caliche in soils of the Mojave Desert, California. Geochimica et Cosmochimica Acta, 49: 57-66. 
Sehgal, J. L., and Stoops, G., 1972. Pedogenic calcite accumulations in arid and semi-arid regions of the Indo-Gangetic alluvial plain of erswhile Punjab (India) - Their morphology and origin. Geoderma, 8: 59-72.

Sehgal, J. L., Gombeer, R., D'Hoore, J., 1976. Clay migration in the formation of argillic horizons in soils developed under varying moisture regimes. Journal of the Indian Society of Soil Science, 24: 20-28.

Simonson, R. W., 1959. Outline of a generalized theory of soil genesis. Soil Science Society of America Proceedings, 23: 152-156.

Simonson, R. W., 1978. A multiple-process model of soil genesis, p. 1-25, in W. C. Mahaney (ed.), Quaternary Soils. Geo Abstracts, Norwich, England.

Smeck, N. E., Runge, E. C. A., and Mackintosh, E. E., 1983. Dynamics and genetic modelling of soil systems, p. 51-81, in L. P. Wilding, N. E. Smeck, and G. F. Hall (eds.), Pedogenesis and Soil Taxonomy. I. Concepts and Interactions. Elsevier Science Publishers B.V., Amsterdam, The Netherlands.

Soil Survey Staff, 1975. Soil Taxonomy. U.S. Department of Agriculture Handbook 436. U.S. Government Printing Office, Washington, DC.

Solomon, S. T., and Walkden, G. M., 1985. The application of cathodoluminescence to interpreting the diagenesis of an ancient calcrete profile. Sedimentology, 32: 877-896.

Stuart, D. M., and Dixon, R. M., 1973. Water movement and caliche formation in layered arid and semiarid soils. Soil Science Society of America Proceedings, 37: 323-324.

Thornthwaite, C. W., 1948. An approach toward a rational classification of climate. Geographical Review, 38: 55-94.

Várallyay, G., 1968. Salt accumulation processes in the Hungarian Danube Valley. 9th International Congress of Soil Science Transactions, I: 371-380.

Walker, G. R., Hughes, M. W., Allison, G. B. and Barnes, C. J., 1988. The movement of isotopes of water during evaporation from a bare soil surface. Journal of Hydrology, 97: 181-197.

Watts, N. L., 1978. Displacive calcite: Evidence from recent and ancient calcretes. Geology, 6: 699-703.

Watts, N. L., 1980. Quaternary pedogenic calcretes from the Kalahari (southern Africa) Mineralogy, genesis, and diagenesis. Sedimentology, 27: 661-686.

White, E. M., 1988. Secondary calcium carbonate in grassland soils in South Dakota. Soil Science, 145: 420-423.

Wieder, M., and Yaalon, D. H., 1974. Effect of matrix composition on carbonate nodule crystallization. Geoderma, 11:95-121.

Wieder, M., and Yaalon, D. H., 1982. Micromorphological fabrics and developmental stages of carbonate nodular forms related to soil characteristics. Geoderma, 28: 203-220. 
Wing, N. R., 1988. Protective barrier and warning marker system development plan. WHC-EP0169 DRAFT. Westinghouse Hanford Co., Richland, WA.

Wood, J. T., and Greenwood, D. J., 1971. Distribution of carbon dioxide and oxygen in the gas phase of aerobic soils. Journal of Soil Science, 22: 281-288.

Wood, W. W., and Petraitis, M. J., 1984. Origin and distribution of carbon dioxide in the unsaturated zone of the Southern High Plains of Texas. Water Resources Research, 20: 1193-1208.

Wright, V. P., 1984. The significance of needle-fibre calcite in a lower Carboniferous palaesol. Geological Journal, 19: 23-32.

Wright, V. P., Platt, N. H., and Wimbledon, W. A., 1988. Biogenic laminar calcretes: Evidence of calcified root-mat horizons in paleosols. Sedimentology, 35: 603-620. 


\section{APPENDIX A}

\section{AN ISSUES HIERARCHY AND PROPOSED WORK PLAN TO STUDY PEDOGENIC CARBONATES IN SOILS AND SEDIMENTS AT THE U.S. DEPARTMENT OF ENERG Y HANFORD SITE, WAS HINGTON}

Layered, earthen protective barriers have been proposed as a means of inhibiting water, plants, and humans and other animals from contacting near-surface hazardous and radioactive wastes buried at the Hanford Site and potentially transporting the contaminants to the groundwater, the land surface, or the air. It is of particular importance to decision makers that there be defensible predictions of the performance of these engineered barriers over their expected lifetime -- up to 10,000 years. Predictions such as these will require new research and testing.

The study of natural analogs is one approach that has been adopted to better understand the potential long-term behavior of engineered barriers. This study examined the feasibility of using pedogenic properties of natural analog soils that have been formed in layered sediments similar to proposed barrier designs to identify past patterns of soil-water movement at the Hanford Site. We concluded that soils are complex sites of biogeochemical and geologic activity, and that a specific feature such as a calcic horizon probably cannot reliably be assumed to have been formed by a single process such as water movement or used to definitively assess past regimes of soil-water movement. This, then, eliminated one of the reasons for studying natural analog soils; that was, to determine from the features of soil profiles whether significant unsaturated recharge occurred in barrier analogs during their formation. We believe that it is likely, however, that pedogenic features, especially horizons of calcium carbonate accumulation, will form in earthen barriers at the Hanford Site during their design life. No information exists at present to predict how hydraulic properties of barriers will change as calcic horizons form. Questions remain unanswered about whether pedogenic features such as horizons of calcium carbonate accumulation would significantly change hydraulic properties of barriers, be beneficial or harmful to several aspects of barrier performance, and when during the life of the barriers, where in the barriers, and in what quantities carbonates would form.

The objective of this appendix is to: 1) organize into a hierarchy the issues associated with using natural analog soils of the Hanford region to predict changes in hydraulic properties that are likely to occur during the lifetime of the engineered waste covers, and 2) to develop a preliminary work plan, based on the issues hierarchy, for a study that will quantify the expected, pedogenically induced, changes in soil hydraulic properties during the lifetime of the protective barriers. 


\section{ISSUES HIERARCHY}

Protective barriers will be designed to isolate buried wastes and inhibit their transport. There are a number of potential transport pathways (e.g., water movement, biointrusion, erosion, und gaseous release). Although pedogenic features (especially the accumulation of $\mathrm{CaCO}_{3}$ to form dense or cemented soil horizons) might deter plants, humans, and other animis from contacting and transporting wastes, the greatest potential effect will be on the movement of water. Consequently, the discussion here focuses on the effect of pedogenesis on the long-term performance of protective barriers using water movement (drainage) as the key performance parameter.

Most of the previously identified and potential natural analog soils in the Hanford area have developed prominent horizons of accumulation of $\mathrm{CaCO}_{3}$ during some part or all of the last 10,000 to 13,000 years. It is also known that, by geologic and pedologic "accident," many of the analog soils that have been formed in layered sequences of sediments are very similar physicslly to designs proposed for the protective barriers. Thus, we can be quite strong in our expectation that if there is $\mathrm{CaCO}_{3}$ either in the parent material of the barriers or arriving onto barriers with eolian dust fluxes, pedogenic $\mathrm{CaCO}_{3}$ will accumulate in the soil profiles of the proposed barriers.

The functional performance of the protective barriers to inhibit water movement, especially unsaturated flow, will depend on the depth, water retention, and hydraulic conductivity of the soil and gravel layers of the barrier. The accumulation of $\mathrm{CaCO}_{3}$ in the soil profile in significant amounts could have a measurable effect on porosity, permeability, and spatial homogeneity or heterogeneity of these properties. If they have a measurable effect, water retention, hydraulic conductivity, and spatial patterns of water movement or concentration in barriers could also change significantly over the operational life of the barriers. There is no information, however, on which to base a prediction of the expected magnitude of change in hydraulic properties of the fine-soil layer caused by $\mathrm{CaCO}_{3}$ accumulations, and thus, whether $\mathrm{CaCO}_{3}$ accumulations would be beneficial or detrimental to the performance of the protective barriers. In addition, although we may be reasonably certain (given the assumptions stated above) that $\mathrm{CaCO}_{3}$ will accumulate in soil protiles of the barriers, we cannot predict where in the soil profiles the accumulation will occur, how much $\mathrm{CaCO}_{3}$ will accumulate, or when during the 10,000-year lifetime of the barriers carbonates will accumulate. If it can be demonstrated that $\mathrm{CaCO}_{3}$ has a significant effect on the hydraulic properties of analog soils and barrier soils, a predictive model will be needed to answer questions such as where, how much, and when. 
As we envision it, the hierarchy of issues related to pedogenic accumulations of $\mathrm{CaCO}_{3}$ in barriers is:

1) If research on, and the design of, waste barriers is focused on maximizing the ability of the fine-soil layer of the barrier to store water and return it to the atmosphere as evapotranspiration and on minimizing the transfer of water to deeper levels in the barrier or waste zones, then water movement through the barriers and changes in hydraulic properties of barrier layers over time obviously are key performance criteria.

2) It is likely that $\mathrm{CaCO}_{3}$ will accumulate in the fine-soil layer or at the fine-coarse interface(s) of barriers at the Hanford Site if there is carbonate in either the parent material of the barriers or the eolian influx to the barriers.

The accumulation of pedogenic $\mathrm{CaCO}_{3}$ in the fine-soil layer may impact hydraulic features such as porosity, pore size distribution, water retention, and hydraulic conductivity. Little or no information is available at present, however, on which to base any estimate of how these features will affect barrier performance.

3) Natural analog soils near the Hanford Site that are 10,000- to 12,000-years old can provide information about the possible changes in soil hydraulic properties that may occur in the tine-soil layers of the protective barriers due to the accumulation of carbonate.

Field and laboratory research on natural analog soils would be employed to determine hydraulic properties of a variety of carbonate-enriched soil horizons relative to comparable but carbonate-free horizons.

4) If pedogenic carbonates significantly change hydraulic properties of analog soils, research will be needed to determine the probable timing of carbonate accumulation, where the carbonate will accumulate, and how much carbonate will accumulate in the fine-soil layers of the protective barriers. In turn, it will be necessary to test the impact of the changing hydraulic properties on water flow and unsaturated recharge in barriers.

Additional field and laboratory research would be employed to refine our understanding of the genesis of natural analog soils, and carbonate movemunt models would be improved and used to predict pedogenic and hydraulic changes to barriers during their operational period. This information would be interfaced with hydrologic modeling efforts to predict impacts of carbonates on water movement. 


\section{Preliminary Study Plan}

We envision a study or research project of 1- to 2-year's duration with a decision point at the end of the first year to determine whether to proceed based on results obtained to this decision point. The major decision to continue will be based on whether there is a demonstrated effect of carbonate on soil hydraulic properties (Part II). If it is found that accumulations of pedogenic $\mathrm{CaCO}_{3}$ significantly affect soil hydraulic properties then it becomes necessary to determine the genesis of carbonates in the natural analogs and the liklihood of similar features forming in the soil mantle of the proposed barriers (Part III). We expect that it will take approximately 1 year to complete parts I and II and another year to complete Part III.

We have proposed a first-year budget that includes funds for a full-time scientist (post-doctoral research associate), a full-time research technician, and equipment and operations.

I. Develop a detailed work plan and quality assurance plan

\section{A. Work plan}

Define the objectives of the study. Describe in detail the criteria for analog site selection and the methoclology for site description and soil sampling along with the analytical techniques for determining pertinent physicochemical properties of sampled soils or sediments.

B. Quality assurance and control

Develop a QA/QC plan in accordance with requirements of PNL.

II. Soil Hydraulic Propertics of Calcic and Noncalcic Horizons

The objective will be to determine if the accumulation of calcium carbonate in soils affects the hydraulic properties of analog soils.

A. Reconnaissance of analog sites at the Hanford Site and the surrounding area

Choose approximately 10 to 15 sites that exhibit a range of carbonate contents and carbonate morphologies, including noncalcic soils that will serve as suitable con-trols.

B. Pilot study

Sample one or two siless to ensure confidence in methodology, both in collection and analysis. 
C. Main study

1. Soil Samples

a. Descibe profiles and lateral variability of soils at sample sites

Dig pits and trenches to describe soil morphology and estimate the degree of spatial variability of calcic horizons.

b. Bulk samples

Sample soils by genetic soil horizons.

c. Undisturbed cores

Obtain undisturbed cores for range of carbonate contents. This may require special sampling techniques due to range in cementation of soil material in calcic horizons.

2. Laboratory analy ses (proposed)

a. Bulk samples

Determine particle size distribution, carbonate content, and particle density.

b. Undisturbed cores

Determine water retention, hydraulic conductivity (saturated and unsaturated), bulk density, and pore size distribution. Total porosity will be calculated from particle density and bulk density.

III. Pedogenesis of Carbonate Accurnulations in Soils and Sediments at the Hanford Site The objective of this phase is to determine how and when carbonates have been formed in analog soils of the Hanford area.

A. Soil Formation

Analysis of pedogenesis will proceed along mainly deductive lines of reasoning based on soil morphology along with age control using tephrochronology and possibly thermoluminescence dating of loess layers. Additional parameters, however, such as measuring carbonate dust flux, soil gas (especially $\mathrm{CO}_{2}$ ) composition, and soil solution composition may be necessary to establish the geochemical control of pedogenic processes of the soils.

1. Soil morphology

Use soil descriptions gathered during Part II to infer processes responsible for soil formation. 


\section{Tephrochronology}

If obvious tephra deposits exist in soil profiles, these will be sampled and the chemical composition of the glass shards will be determined using an electron microprobe. If tephras exist only in indistinct horizons then incremental sampling (e.g., $5 \mathrm{~cm}$ ) will be used to obtain samples and specialized techniques (density separation) will be necessary to isolate the glass shards for microprobe analysis. The tephras that are most likely to be found include Mount St. Helens "Set S" (13,000 years BP) and Mazama (6800 years BP). The location of tephras should define major episodes of erosion and sediment deposition, along with the timing of soil-forming processes.

3. Thermoluminescence Dating

Thermoluminescence dating of increments of loess in key analog soils may also provide age control on the timing of major soil-forming processes and the rate of erosion and deposition processes.

\section{Geochemistry}

Measure $\mathrm{CaCO}_{3}$ content of eolian dust, monitor soil gas $\left(\mathrm{CO}_{2}\right)$ composition, and determine interaction between solution and solid phases in the soil.

\section{B. Modeling of Pedogenic Carbonates}

If carbonate accumulations are shown to be important to hydraulic properties, then it is necessary to predict when, where, and how much carbonate may accumulate in the proposed barrier soil profile. A simulation model will be needed to accomplish task. The level of sophistication needed to accomplish this prediction remains unknown at this time and will need to be explored further. 

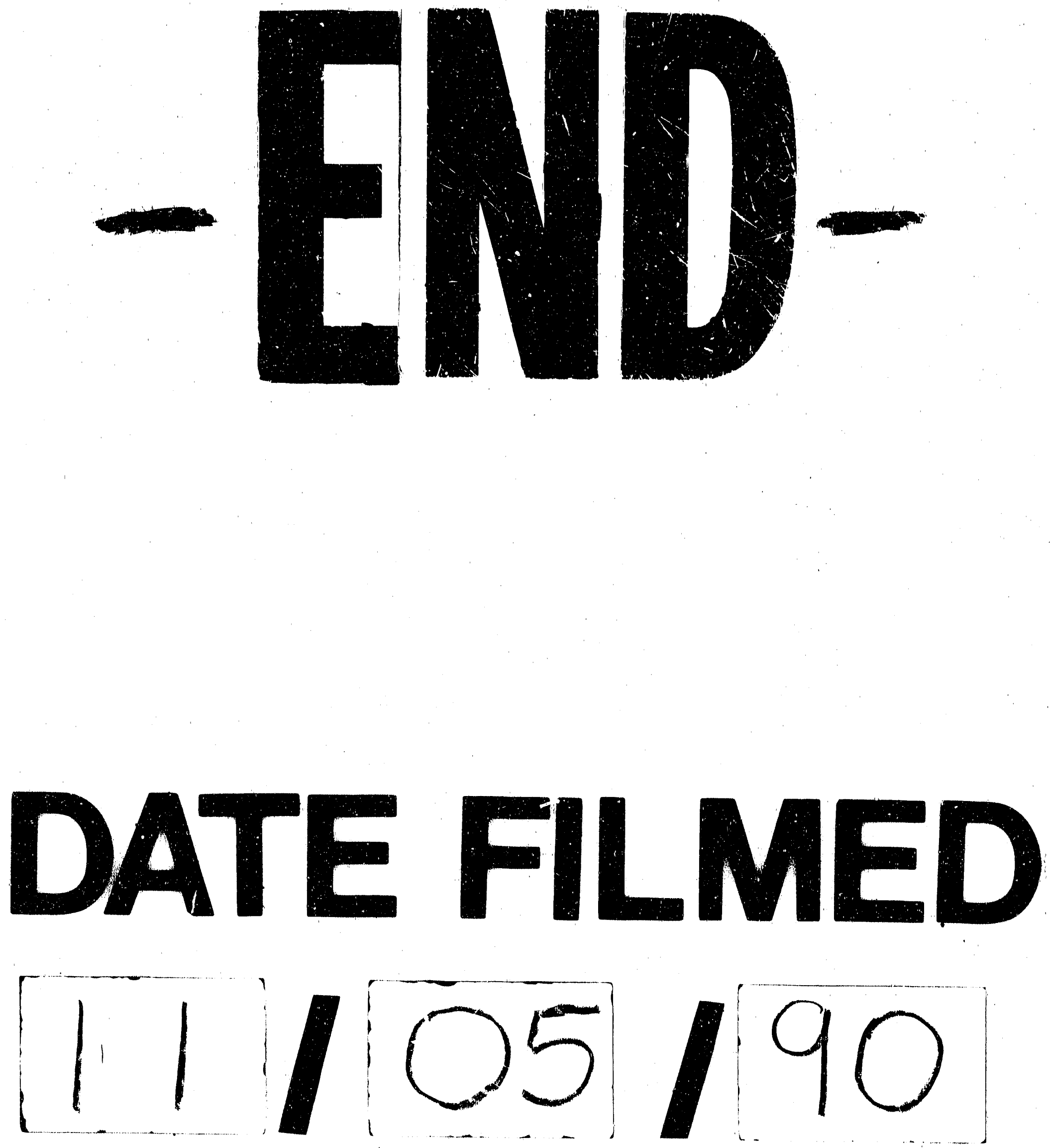
